\title{
Nanoplankton protists from the western Mediterranean Sea. II. Cryptomonads (Cryptophyceae $=$ Cryptomonadea)*
}

\author{
GIANFRANCO NOVARINO \\ Department of Zoology, The Natural History Museum, Cromwell Road, London SW7 5BD, U.K. \\ E-mail: gn@nhm.ac.uk
}

\begin{abstract}
SUMMARY: This paper is an electron microscopical account of cryptomonad flagellates (Cryptophyceae = Cryptomonadea) in the plankton of the western Mediterranean Sea. Bottle samples collected during the spring-summer of 1998 in the Sea of Alboran and Barcelona coastal waters contained a total of eleven photosynthetic species: Chroomonas (sensu auctorum) sp., Cryptochloris sp., 3 species of Hemiselmis, 3 species of Plagioselmis including Plagioselmis nordica stat. nov/sp. nov., Rhinomonas reticulata (Lucas) Novarino, Teleaulax acuta (Butcher) Hill, and Teleaulax amphioxeia (Conrad) Hill. Identification was based largely on cell surface features, as revealed by scanning electron microscopy (SEM). Cells were either dispersed in the water-column or associated with suspended particulate matter (SPM). Plagioselmis prolonga was the most common species both in the water-column and in association with SPM, suggesting that it might be a key primary producer of carbon. Taxonomic keys are given based on SEM.
\end{abstract}

Key words: Cryptomonadea, cryptomonads, Cryptophyceae, flagellates, nanoplankton, taxonomy, ultrastructure.

RESUMEN: Protistas nanoplanctónicos del Mar Mediterraneo Noroccidental II. Cryptomonadales (CryptophyCEAE $=$ CRYPTOMONADEA $).-$ Este estudio describe a los flagelados cryptomonadales $($ Cryptophyceae $=$ Cryptomonadea planctónicos del Mar Mediterraneo Noroccidental mediante microscopia electrónica. La muestras recogidas en botellas durante la primavera-verano de 1998 en el Mar de Alboran y en aguas costeras de Barcelona, contenian un total de 11 especies fotosintéticas: Chroomonas (sensu auctorum) sp., Cryptochloris sp., 3 especies de Hemiselmis, 3 especies de Plagioselmis incluyendo Plagioselmis nordica stat. nov/sp. nov., Rhinomonas reticulata (Lucas) Novarino, Teleaulax acuta (Butcher) Hill, y Teleaulax amphioxeia (Conrad) Hill. La identificación estaba basada principalmente en las características de la superficie celular, la cual se ponia de manifiesto mediante el microscopio electrónico de barrido (SEM). Las células estaban o, dispersas en la columna de agua o asociadas a materia orgánica particulada (SPM). Plagioselmis prolonga era la especie mas común tanto en la columna de agua como asociada a la materia orgánica particulada (SPM), sugiriendo que podia ser un productor primario clave de carbono. Las llaves taxonómicas dadas estan basadas en SEM

Palabras clave: Cryptomonadea, cryptomonadales, Cryptophyceae, flagelados, nanopláncton, taxonomía, ultraestructura.

\section{INTRODUCTION}

Cryptomonad flagellates (Cryptophyceae = Cryptomonadea) are widespread and abundant in the sea, particularly in the pelagic environment

*Received January 28, 2002. Accepted September 10, 2004.
(Haigh et al., 1992), where photosynthetic forms may be responsible for a large part of primary carbon production (Robinson et al., 1999). However, very few ecological surveys of marine plankton have attempted to identify cryptomonads down to the genus or species levels. Perhaps this is partly due to the state of flux of cryptomonad systematics 
(Novarino and Lucas, 1993a, 1995, Clay et al., 1999), and the consequent scarcity of firmly established taxonomic criteria and up-to-date identification guides. Nonetheless, there are several reasons why it is important to identify specimens as far as possible:

Cryptomonad diversity may be far from having been described in full. The total number of species has been estimated at about 1200 , i.e. six times more than are currently known (Andersen, 1992). Therefore, it is always possible that environmental samples will contain previously undescribed taxa, perhaps with novel morphological, ecological, physiological or other features of interest within the context of cryptomonad systematics and phylogeny. Furthermore, our knowledge of how diversity varies in relation to geographical and environmental variability is still scant, and the possibility of addressing these questions depends entirely on the ability to recognize species in the first place.

In coastal areas, cryptomonads may form nuisance blooms (Andreoli et al., 1986; Dame et al, 2000). Sound taxonomic identifications are necessary to any modelling studies of such blooms if the models are to be sufficiently predictive.

There is evidence that freshwater cryptomonad species may differ considerably from one another in their physiological and ecological characteristics, and therefore they may occupy distinct, welldefined ecological niches (Sommer, 1992; Gervais, 1997). Although there is scant information on the subject in marine environments, a priori it cannot be excluded that the situation is analogous to that in freshwaters. Here again, the ability to address this sort of question will depend on the availability of reliable taxonomic identifications.

This paper is the second in a series on the diversity and ecological significance of nanoplankton protists (mostly flagellates excluding coccolithophorids, and naked ciliates) in the western Mediterranean Sea (Novarino et al., 2002). It is a first attempt at investigating cryptomonad diversity in the Mediterranean using scanning electron microscopy (SEM), which provides much taxonomic information (e.g. Novarino, 2003, and references therein). What little is known on Mediterranean cryptomonads derives mostly from an early study on the Adriatic Sea phytoplankton (Schiller, 1925) where six species (all newly described and hardly reported since) were found: Cryptochloris vittata Schiller, Cryptomonas adriatica Schiller, Hillea fusiformis Schiller, Rhodomonas caerulea Schiller,
$R$. gracilis Schiller and $R$. ruttneri Schiller. More recently, other cryptomonad species have been reported during ecological investigations on the Mediterranean plankton, including studies carried out in the western region (Margalef, 1969), but with very few exceptions they have not been identified to the genus or species levels. Using electron microscopy, a bloom-forming cryptomonad in the Adriatic was tentatively identified as a member of the genus Chroomonas (Andreoli et al., 1986; more recently it was also argued that this cryptomonad may be a species of Plagioselmis: Novarino et al., 1994). Finally, in an atlas of Mediterranean phytoplankton there is an SEM micrograph of a cryptomonad (Cryptomonas sp.: Delgado and Fortuño, 1991).

\section{MATERIAL and METHODS}

\section{Sampling}

About 60 samples collected from the Sea of Alboran and Barcelona coastal waters (Llobregat-Besós transect and time-series samples) were processed and examined using field-emission scanning electron microscopy (SEM) as described elsewhere (Novarino et al., 2002). Measurements were taken on enlarged photographic prints of Lugol-fixed cells. The terms "length", "width" and "thickness", as applied to cryptomonad cells, refer to the length of the longitudinal, perlateral, and dorso-ventral axes respectively; when the value of the cell width is not specified in the descriptions, the width is very similar or equal to the cell thickness. When a cryptomonad cell is seen from the ventral face, the "right" and "left" sides of the cell are to the left- and right-hand sides of the observer respectively. The expression "size of the periplast plates", where applicable, refers to the length of the sides of the hexagonal or rectangular periplast plates. "Known geographical distributions" only include records based on electron microscopy. Cryptomonads are ambiregnal protists, and therefore they fall under the dual jurisdiction of the botanical (ICBN) and the zoological (ICZN) Codes of Nomenclature (Novarino and Lucas, 1993a, 1995).

\section{Taxonomic identification criteria}

Traditionally, cryptomonad taxonomy, systematics and identification have been elusive because the 
early taxonomic descriptions were based necessarily on the small number of characters visible using light microscopy (e.g. cell shape and size, length of flagella, colour and number of chloroplasts, presence or absence of pyrenoids). During the last three or four decades electron microscopy has revealed a wealth of previously undescribed cellular features, many of which have been included in a comprehensive review of characters of possible taxonomic value within the cryptomonads (Klaveness, 1985). Several ultrastructural characters have been used for describing new genera and species, and amending existing generic diagnoses (Hill and Wetherbee, 1986, 1988, 1989, 1990; Hill, 1991a; Novarino, 1991a; Hill, 1991b; Novarino, 1991b; Novarino and Lucas, 1993a; Novarino et al., 1994; Kugrens et al., 1999). Subsequently, two attempts have been made to erect formal classification systems of the cryptomonads based on ultrastructural characters (Novarino and Lucas, 1993a, 1995; Clay et al., 1999). More recently, molecular sequence data have been used to infer the phylogenetic relationships of the group and those within the group itself (McFadden et al., 1994; Cavalier-Smith et al., 1996; Marin et al., 1998; Hoef-Emden et al., 2002).

There is still some discussion about which ultrastructural characters are taxonomically significant, and at what level. The list below (based on Novarino, 2003) summarises a number of characters which are visible using SEM and are accorded a taxonomic value at the generic and/or specific levels by various workers. However, in spite of its great usefulness SEM does not make it possible to identify conclusively all known cryptomonad species because further information might be necessary on the identity of the accessory photosynthetic phycobilin pigment, the detailed architecture of the periplast (as revealed by freeze-fracture/etch methods) and the internal cell ultrastructure, especially the position of the nucleomorph (as revealed by transmission electron microscopy).

Cell size and shape. Strictly speaking these are not "ultrastructural" characters, but SEM makes it possible to observe the cell shape much more accurately than is possible using light microscopy alone. This is important because cell shape parameters may be taxonomically significant at the species level, e.g. shape of the cell apex and antapex, dorso-ventral or lateral compression, and torsion or curvature of the cell along its longitudinal axis (Hill and Wetherbee, 1986, 1988, 1989; Hill, 1991a; Novarino, 1991a; Hill, 1991b; Novarino, 1991b; Gervais, 1997;
Kugrens et al., 1999). The SEM also makes it possible to measure specimens very accurately. Shrinkage (up to about $25 \%$ linear) may occur during specimen preparation for SEM using critical point-drying (Novarino, 1991b; Novarino and Lucas, 1993a), and this should be borne in mind when comparing measurements based on SEM and light microscopy.

Kind of periplast present. Plated versus non-plated periplasts are accepted as a taxonomically significant character at the generic level (Santore, 1984; Kugrens and Lee, 1987; Hill and Wetherbee, 1988, 1989, 1990; Hill, 1991a; Novarino, 1991a; Hill, 1991b; Novarino, 1991b; Novarino and Lucas, 1993a, 1993b; Novarino et al., 1994; Novarino and Lucas, 1995; Clay et al., 1999; Kugrens et al., 1999). Detailed investigations on periplast architecture may require freeze-fracture/etch preparations for transmission electron microscopy (Wetherbee et al., 1986, 1987; Kugrens and Lee, 1987), but SEM is usually capable of revealing whether the periplast is plated or non-plated.

Shape and size of the periplast plates when plates are present. The shape of the periplast plates has been used extensively as a taxonomic character at the generic level (Santore, 1984; Kugrens and Lee, 1987; Hill and Wetherbee, 1988, 1989, 1990; Hill, 1991a; Novarino, 1991a; Hill, 1991b; Novarino, 1991b; Novarino and Lucas, 1993a, 1993b; Novarino et al., 1994; Novarino and Lucas, 1995; Clay et al., 1999; Kugrens et al., 1999), while the size of the plates has been used to delimit species within particular genera (Meyer and Pienaar, 1984; Novarino, 1991a, 1991b; Novarino and Lucas, 1993b; Novarino et al., 1994; Kristiansen aand Kristiansen, 1999). When one is measuring the periplast plates, the possible occurrence of shrinkage artefacts (see below) should be borne in mind and may require some interpretation on the part of the observer.

Morphology of the vestibular region of the cell from which the flagella arise, especially the presence or absence of a true, non artefactual ventral furrow. This has been the object of much controversy ever since the early light-microscopical descriptions. The term "furrow" refers to a shallow groove on the ventral face of the cell, of variable length and width. Some of the early light microscopists described cryptomonads with open furrows, but the exact architecture of these structures (especially their spatial relationships with other vestibular structures such as the closed, tubular gullet) was virtually impossible to establish with certainty using light microscopy only. Since the advent of electron 
microscopy, SEM has been the tool of choice for studying these structures. It has been hypothesised (Santore, 1984) that furrows are always preparation artefacts, and therefore they have no taxonomic value at all, or that they are never artefactual (Kugrens et al., 1986; Hill and Wetherbee, 1989) and are taxonomically significant at the generic level (Clay et al., 1999). A more complex view is that the term "furrow" may encompass artefactual and non-artefactual structures alike (Novarino, 1991b), and it is possible to judge whether or not an observed furrow is an artefact based on a few simple considerations (presence or absence of obvious signs of shrinkage or collapse in other regions of the cell; frequency of occurrence of observed furrows in a sample of 30-40 cells belonging to the same species; and, in cryptomonads with a plated periplast, presence or absence of periplast plates on the internal face of the furrow, because true furrows are never lined internally with discrete periplast plates of the same kind as those found on the rest of the cell). Further comments on the relationships between artefacts and furrow-like structures are made below. It has been argued that true furrows are taxonomically significant at the specific rather than generic level because they are not necessarily present in all of the species of a particular genus (Novarino, 1991b; Novarino et al., 1994).

Arrangement, absolute and relative length of the flagella. Flagella can be observed also with the light microscope but their length and point of insertion can be determined much more accurately with the SEM. Features such as the median/subapical versus apical insertion point of the flagella and their absolute and relative length have been considered to be taxonomically significant since the times of the early light-microscopical descriptions (at the genus and species level respectively). This view has been upheld also in more recent ultrastructural and taxonomic investigations (Hill and Wetherbee, 1988; Novarino and Lucas, 1993b; Clay and Kugrens, 1999).

Presence or absence of a posterior tail. "Tails", i.e. acute posterior ends which are often curved ventrally or dorsally, can be observed also with the light microscope, but the SEM can show whether or not the periplast is of the same kind present on the rest of the cell surface. This feature is taxonomically significant at the generic level because it is diagnostic of Plagioselmis (Novarino et al., 1994).

Presence or absence of a mid-ventral band in the region between the posterior end of the furrow and the posterior end of the cell. Mid-ventral bands are present in some genera. They are easily observed with the SEM, where they appear as a cord-like structure on the ventral cell surface in the posterior region of the cell. Within individual genera they do not appear to be present in all of the species (Hill and Wetherbee, 1989; Hill, 1991b; Novarino et al., 1994), suggesting that their taxonomic value is at the specific level.

Presence or absence of a periplast raphe. The "raphe" $-\mathrm{a}$ line at the posterior end of the cell where the periplast plates seem to converge-is a unique feature of some species of the genus Chroomonas sensu auctorum (Hill, 1991b).

Arrangement of flagellar appendages. The nature and arrangement of flagellar appendages in cryptomonads are highly diversified (Morrall, 1980; Kugrens et al., 1987). The taxonomic significance of these appendages is not entirely clear but some genera always show a characteristic pattern. Whole mounts for transmission electron microscopy are the choice observation method but the SEM may still show the appendages in adequately fixed cells, revealing whether or not they are arranged according to the "normal" pattern, i.e. two rows of tubular hairs on the dorsal (usually longer) flagellum, and one row on the ventral (usually shorter) flagellum.

\section{RESULTS AND DISCUSSION}

\section{Occurrence}

Cryptomonads were found in all areas investigated. They occurred either as dispersed (non particle-associated) cells or in association with suspended particulate matter (SPM) (Fig. 1). Amongst SPM-associated forms, species of Plagioselmis and Hemiselmis were the most frequent (Fig. 1). Cells of Plagioselmis formed aggregates incorporating variable amounts of flocculent or fibrillar particulate material and other protists (e.g. diatoms or diatom remains, Fig. 1A; dinoflagellates, Fig. 1B; and other flagellates, especially Hemiselmis, prasinophytes, and Phaeocystis, Figs. $1 C, D)$. Adhesion to SPM or other protists occurred either over a large portion of the cell surface (Figs. 1A-C), or else it was limited to a few points, as in the case of cells adhering to chitinous exofilaments produced by the haptophyte Phaeocystis (Fig. 1D). Eleven species belonging to six genera were found. All were photosynthetic, as 


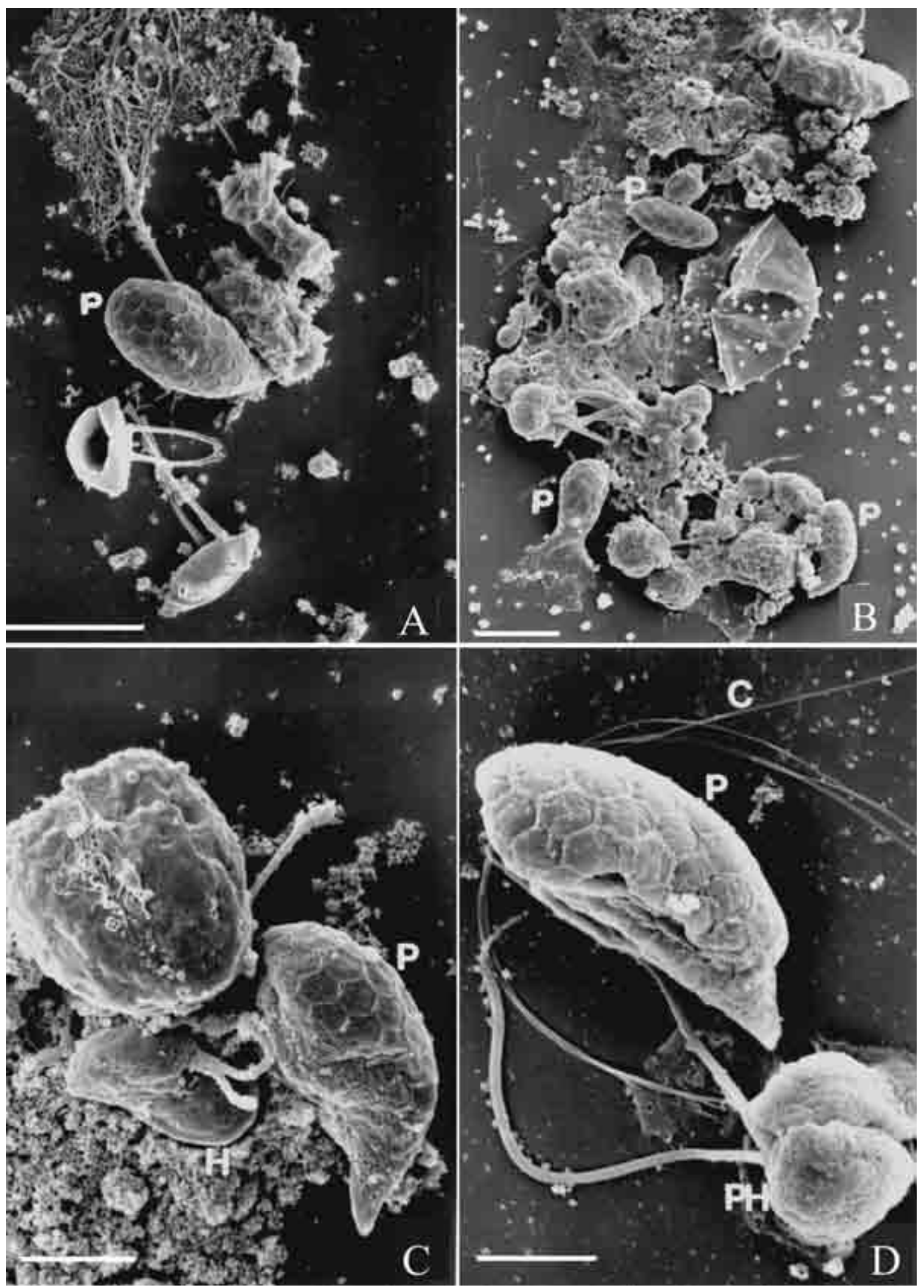

FIG. 1. - Cryptomonads from the Mediterranean Sea, SEM, HMDS-dried material, showing that the cells may occur in association with suspended particulate matter (SPM). A, a cell of Plagioselmis prolonga $(\mathrm{P})$ associated with diatom remains and fibrous material. B, other cells of $P$. prolonga $(\mathrm{P})$ associated with a larger aggregate including a thecate dinoflagellate, various small flagellate cells and large quantities of granular material. C. A cell of $P$. prolonga $(\mathrm{P})$ associated with Hemiselmis sp. inedit. $(\mathrm{H})$, a prasinophyte cell and granular material. D, a cell of $P$. prolonga $(\mathrm{P})$ associated with the chitinous exofilaments produced by the haptophyte Phaeocystis $(\mathrm{P})$. Scale bars $=5 \mu \mathrm{m}(\mathrm{A}, \mathrm{B}), 2.5$ $\mu \mathrm{m}(\mathrm{C})$ or $2 \mu \mathrm{m}(\mathrm{D})$. 
expected on the basis of the fact that heterotrophic cryptomonads are mostly freshwater rather than marine forms (Chilomonas Ehrenberg), or frequently restricted to benthic environments when they occur in the sea (Goniomonas von Stein).

\section{General appearance in SEM}

The cell surface (periplast) is of great taxonomic value within the cryptomonads (Novarino and Lucas, 1993a; Clay et al., 1999; Novarino, 2003), and it was also the most prominent feature of the specimens found during this investigation. The following account of periplast morphology in the Mediterranean material is aimed at providing as much information as possible for the practical identification of specimens during future ecological surveys.

In specimens fixed adequately with Lugol's solution the periplast morphology was that expected for any particular genus. Thus cells of Plagioselmis had a characteristic periplast composed of large hexagonal plates on the main portion of the cell body, and a sheet-like (= non-plated) periplast on the posterior tail (Figs. 2A, 8A, 9A). Hemiselmis (Figs. 3, 5-7) also had hexagonal plates, but they were much larger than those of Plagioselmis; additionally, cells of Hemiselmis lacked a tail with a sheet-like periplast. The plates of Rhinomonas (Fig. 13B) were also hexagonal but usually smaller than those of Plagioselmis. Chroomonas sensu auctorum had rectangular plates (Fig. 13A), whereas Cryptochloris (Fig. 4) and Teleaulax (Figs. 11, 12) had a non-plated (= sheet-like) periplast.

Occasionally, preparation artefacts occurred which gave rise to deviations from the normal appearance of the periplast, particularly in the case of glutaraldehyde-fixed material. These artefacts are documented here for future reference and identification purposes because they might still provide useful taxonomic information when the periplast lacks its normal appearance. Within the cryptomonads, typical artefacts associated with SEM preparation schedules can be subdivided into three broad groups as follows:

Artefacts arising from peripheral ejectosome discharge or bulging. The discharge of ejectosome vesicles present underneath the cell membrane produces distinctly visible pores (e.g. Fig. 2C), which may provide information on periplast morphology when the normal appearance is not seen. In cryptomonads with a plated periplast, the peripheral ejectosomes are placed at the corners of the plates so their discharge immediately reveals the plate shape (e.g. Plagioselmis, Fig. 2C: hexagonal plates and ejectosome pores arranged according to an hexagonal pattern). When the periplast is sheet-like (= nonplated) the peripheral ejectosomes are frequently arranged in a spiral pattern; bulging of the ejectosomes towards the external surface immediately reveals this arrangement, showing in turn that the periplast is not plated (e.g. Teleaulax, Fig. 11D). In the case of the posterior tail of Plagioselmis, bulging and/or discharge of the peripheral ejectosomes clearly reveals that the tail periplast is sheet-like rather than plated (Fig. 2A). The presence of a sheetlike periplast on the tail, as opposed to a plated (hexagonal) periplast on the main portion of the cell body, is a diagnostic feature of the genus Plagioselmis, making it possible to tell apart all members of this genus from other cryptomonads in which the cell posterior end is also pointed and tail-like, e.g. Teleaulax (Figs. 11, 12).

Artefacts arising from inadequate fixation of the cell membrane. These artefacts are very variable and it is difficult to give an unequivocal interpretation of how they affect the appearance of the periplast because cryptomonad cells may have periplast components on one, the other or both sides of the cell membrane. In the case of periplast plates present only on the inside of the membrane (e.g. Plagioselmis, Figs. 2B, D), the complete loss of the membrane may give rise to plates with a smooth, more angular appearance (Fig. 2D). A similar appearance may be seen in some Hemiselmis cells where the plates may often deform (Fig. 3D). At times the plates may be bordered by thickened ridges (e.g. Plagioselmis, Fig. 3A; Hemiselmis, Fig. 3C). Adequately fixed cells usually lack these ridges and have thin grooves instead (e.g. Fig. 6), so the ridges could be a result of inadequate fixation of the membrane over the intra-membrane particles present between adjoining periplast plates (see Kugrens and Lee, 1987). Shrinkage of the membrane over the underlying (internal) periplast plates may give rise to either a more distinct or indistinct appearance of the plates, depending on the degree of shrinkage itself (e.g. Plagioselmis, Fig. 2B; Hemiselmis, Fig. 3B). Cell shrinkage (up to about $25 \%$ linear) is to be considered normal during specimen preparation for SEM (Novarino, 1991b), so it is possible that membrane shrinkage itself is a main factor contributing to the "normal" appearance of the periplast in SEM. 


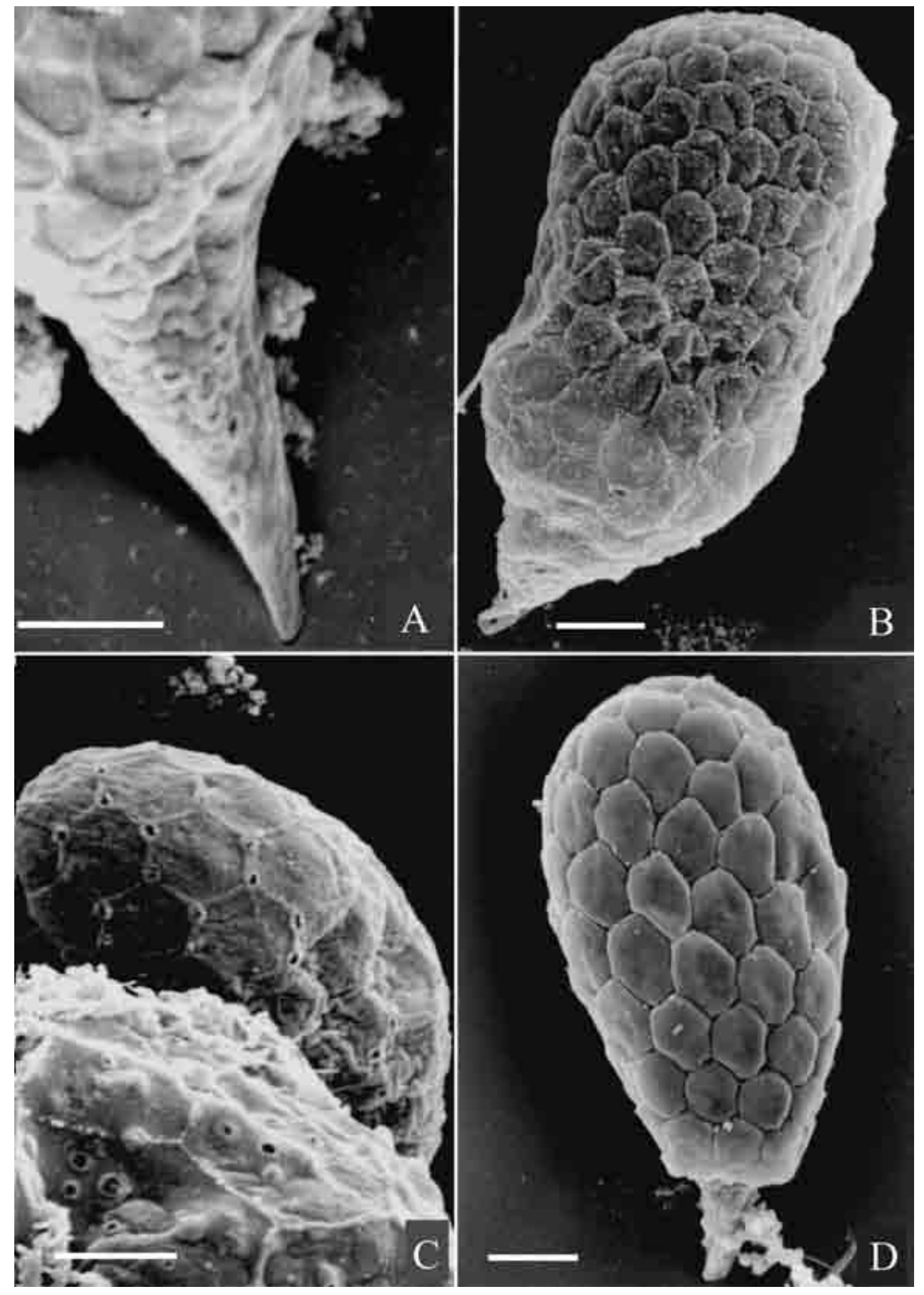

FIG. 2. - Cryptomonads from the Mediterranean Sea, SEM, HMDS-dried material, showing the variability of the appearance of the periplast of Plagioselmis prolonga also in relation to fixation. A, the posterior tail of Plagioselmis prolonga, which has a characteristic sheet-like periplast rather than the hexagonal plates present on the main portion of the cell body; some ejectosome pores are also visible. B, a cell from which the cell membrane has been removed by fixation in the anterior half of the cell, producing a more angular and "rougher" appearance of the underlying periplast plates. C, cells of P. prolonga (top) and Hemiselmis (bottom), showing that the hexagonal plates of Plagioselmis are smaller than those of Hemiselmis; note also the ejectosome pores at the corners of the plates of Plagioselmis. D, a cell of Plagioselmis with the cell membrane completely removed by fixation; compare the appearance of the periplast plates with Figs. $2 \mathrm{~B}$ and $2 \mathrm{C}$. Scale bars $=1 \mu \mathrm{m}$. 

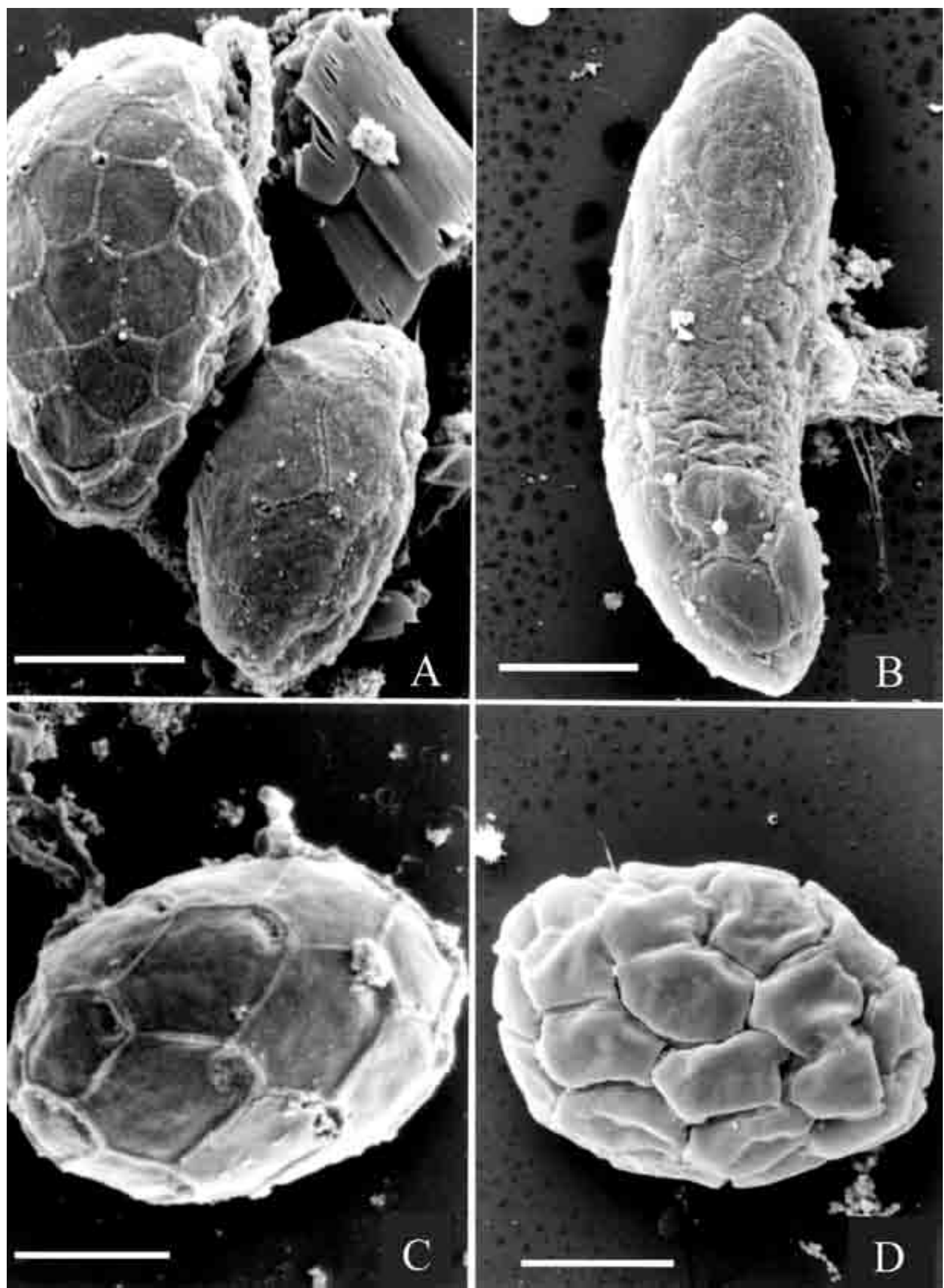

FIG. 3. - Cryptomonads from the Mediterranean Sea, SEM, HMDS-dried material, showing the variability of the appearance of the periplast of Hemiselmis also in relation to fixation. A, a cell of Hemiselmis (right), whose periplast plates are characteristically larger than those of Plagioselmis (left). B, a dividing cell of Hemiselmis, in which the periplast plates of one of the daughter cells (top) are indistinct. C, a cell showing ridges between the periplast plates, probably as a result of inadequate fixation of the cell membrane over the intra-membrane particles between adjoining plates. D, a cell where inadequate fixation has completely removed the cell membrane, producing distortions within the underlying periplast plates. Scale bars $=2 \mu \mathrm{m}$. 
Artefactual ventral furrow-like structures. These artefacts are very misleading because cryptomonad cells may also possess true, non-artefactual ventral furrows (Novarino, 1991b; Novarino, 2003). When the observed furrow is a narrow fold-like structure then it is most probably an artefact associated with cell shrinkage occurring during preparation for SEM. Such shrinkage may also produce folds or cracks in other parts of the cell, especially the dorsal face (Fig. 13B). In cryptomonad cells with a plated periplast it is possible to tell unequivocally whether or not an observed furrow is artefactual because true furrows are never lined internally with periplast plates (Figs. 5C, 8C). In the case of cells with a nonplated periplast, true furrows are usually broad and they often show ejectosome pores on their internal surface (Fig. 12B).

\section{SEM-based identification key to the genera}

The following artificial key to the genera found during this investigation is based mostly on the main features of the periplast, as revealed by SEM.

1. Cells with a sheet-like periplast, i.e. not composed of separate plates 2

- Cells with a periplast composed of separate plates .............................................................. 3

2. Large $(>8-10 \mu \mathrm{m})$, elongated or elliptical cells with an acute posterior end where the periplast is also sheet-like Teleaulax

- Smaller (ca. $5 \mu \mathrm{m}$ ) subspherical cells

Cryptochloris

3. Periplast plates rectangular.

Chroomonas sensu auctorum

- Periplast plates hexagonal ...4

4. Plates large (not less than 0.4-0.5 $\mu \mathrm{m}$ ), present on the entire cell surface including the posterior end, which may be pointed and therefore superficially resemble the tail of Plagioselmis (compare couplet 5 below); cells small (usually up to $5 \mu \mathrm{m}$ long) and reniform, with median or subapical flagella Hemiselmis

- Smaller plates (up to about $0.5 \mu \mathrm{m}$ ); cells usually longer than $5 \mu \mathrm{m}$, not reniform, with apical flagella

5. The posterior end is modified into a pointed tail, possessing a mid-ventral band and a sheet-like periplast instead of the plated periplast found on the main portion of the cell body ..Plagioselmis

- The posterior end is not modified into a tail ...... Rhinomonas

\section{Taxonomy}

Genus Cryptochloris Schiller (ICBN, ICZN) non Bentham (ICBN) non Shortridge and Carter (ICZN)

Schiller, 1925, Archiv für Protistenkunde vol. 53, p. 88, pl. 3 Fig. 10.

Type species: Cryptochloris vittata Schiller, 1925, p. 88, pl. 3 Fig. 10.

Cryptochloris sp. Novarino, Mills and Hannah (Figs. 4, 14A)

Novarino et al., 1997, p.1093, Figs. 5e, 9, 10.

Bérard-Therriault et al., 1999, p. 249, pl. 114 Figs. d, e, g-i (as Cryptochrysis sp., typographical error for Cryptochloris sp.).

Known geographical distribution: Mediterranean Sea: Sea of Alboran; Northern Atlantic: southern North Sea (Novarino et al., 1997), Irish Sea (Novarino, unpublished), St. Lawrence estuary and gulf (Bérard-Therriault et al., 1999).

Cryptochloris is a scarcely known genus originally described from the plankton of the Adriatic Sea. To date it only includes the type-species, $C$. vittata Schiller (1925), a photosynthetic flagellate with two unequal flagella and a ventral groove (furrow) lined with ejectosomes, which has never been reported again after the original description. The first report of this genus after the original description is given by the finding of Cryptochloris sp. in the plankton of the southern North Sea (Novarino et $a l .$, 1997). Identification was based on SEM, which showed cells with two equal flagella and a ventral furrow bordered by a "lip" (thickened margin) and lined with ejectosome pores. The only other published report of Cryptochloris is from the plankton of the St. Lawrence estuary and gulf (Bérard-Therriault et al., 1999). This is under the name of Cryptochrysis $\mathrm{sp}$. but this is clearly a typographical error for Cryptochloris since the specimens illustrated using SEM are very similar the North Sea specimens of Cryptochloris sp. (Novarino et al., 1997), to which express reference was made by Bérard-Therriault et al. (1999); express reference was also made to " $C$. vittata Schiller 1925". During the present investigation we found Cryptochloris specimens very similar to those from the St. Lawrence and the North Sea. Very likely the specimens described from all of these localities belong to a hitherto undescribed species, but further information is necessary for a formal taxonomic description.

Cells of Cryptochloris sp. from the Mediterranean (Figs. 4, 14A) are subspherical, about 4-6 $\mu \mathrm{m}$ 

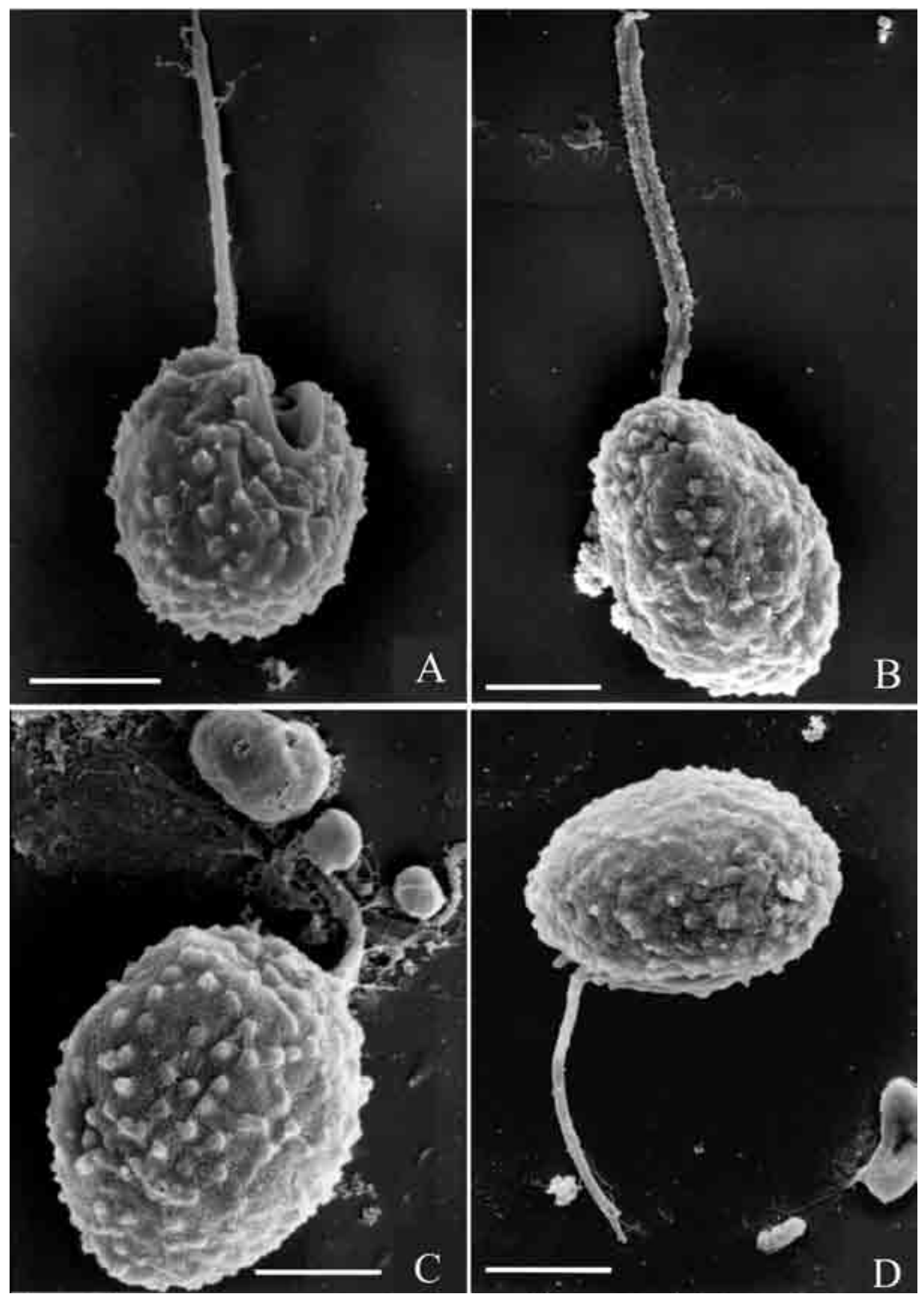

FIG. 4. - Cryptochloris sp. Novarino et al. from the Mediterranean Sea, SEM, HMDS-dried material. A, this cell is in ventro-lateral view as seen from the posterior end; it shows the characteristic ventral furrow bordered by a thickened, lip-like margin. B, a cell in dorsal view. C, a closer view of the periplast of a cell seen in dorsal view; note the papillate appearance produced by the bulging peripheral ejectosomes lying underneath the cell membrane. $\mathbf{D}$, a cell in lateral view. Scale bars $=2 \mu \mathrm{m}$. 
long and 3.5-5 $\mu \mathrm{m}$ thick. There are two equal flagella about 1-1.5 times the cell length, arising from a vestibular depression displaced towards the righthand side of a ventral furrow (Fig. 14A). The flagella may have a scaly appearance (Fig. 4B) but the structure of the scales is unknown. The furrow reaches the median part of the cell and is characteristically bordered by a thickened, lipped margin (Fig. 4A). The periplast has a papillate appearance (Fig. 4C), most likely reflecting the arrangement of underlying peripheral ejectosomes. Specimens from the North Sea (Novarino et al., 1997) are very similar to the Mediterranean ones. Those from the St. Lawrence (Bérard-Therriault et al., 1999) are larger (on average $8 \times 6.4 \mu \mathrm{m}$ ) and more elliptical in shape, sometimes with a slightly pointed posterior end, as described for the type species Cryptochloris vittata (Schiller 1925, p. 88, pl. 3 Fig. 10).

During this investigation this species was found in the Sea of Alboran stations B and C at depths between 40 and $140 \mathrm{~m}$, i.e. at or below the deep chlorophyll maxima which were located between 26 and $44 \mathrm{~m}$.

Note on ambiregnal generic nomenclature. There are three homonyms of the name Cryptochloris. Two of these are under the jurisdiction of the ICBN, i.e. Cryptochloris Schiller and the senior (earlier) homonym Cryptochloris Bentham, a name of a genus of grasses published in 1882. Owing to the existence of this homonym the name Cryptochloris Schiller is illegitimate under the ICBN. However, a proposal has been submitted to conserve Cryptochloris Schiller under the ICBN and at the same time reject Cryptochloris Bentham (Novarino and Gilbert, 2002). The latter is not in current use and the replacement of Cryptochloris Schiller under the ICBN would be disadvantageous from the point of view of ambiregnal nomenclature because Cryptochloris Schiller is a perfectly acceptable name under the ICZN. Cryptochloris Schiller has a junior (later) homonym under the ICZN, i.e. Cryptochloris Shortridge and Carter, a name of a genus of mammals published in 1938 which ought to be replaced with an appropriate substitute in accordance with the nomenclatural rules.

\section{Genus Hemiselmis Parke (ICBN, ICZN)}

Parke, 1949. Journal of the Marine Biological Association of the United Kingdom Vol. 28, p. 279, pl. II Figs. 11-16, text-Figs. 69-73.

Type species: Hemiselmis rufescens Parke, 1949, p. 279, pl. II Figs. 11-16, text-Figs. 69-73.

\section{Key to the species found here}

1. Furrow present Hemiselmis sp. inedit.

- Furrow absent 2

2. Flagella equal in length and shorter than the cell; periplast plates very large (on average about 0.75 $\mu \mathrm{m})$ Hemiselmis sp. 1

- Flagella longer than the cell, with the dorsal flagellum slightly longer than the ventral one; periplast plates smaller (on average about 0.5 $\mu \mathrm{m})$ Hemiselmis sp. 2

\section{Hemiselmis sp. inedit.} (Figs. 5, 14B)

Known geographical distribution: So far found only in the Mediterranean Sea (Sea of Alboran, port of Barcelona).

Cells of Hemiselmis sp. inedit. (Figs. 5, 14B) are about 3-4 $\mu \mathrm{m}$ long and 1.5-2 $\mu \mathrm{m}$ thick. There are two unequal or subequal flagella, of which the longer (dorsal) one is just longer than the cell. The dorsal flagellum carries the usual double row of tubular hairs, while the ventral one has a single row (Fig. 5B). The flagella are inserted at an angle of up to about $50-60^{\circ}$ with respect to the longitudinal axis of the cell, and arise from a vestibular depression displaced towards the right-hand side of a ventral furrow (Fig. 5C, 14B). In SEM preparations the furrow may be lined with ejectosome pores. The periplast is composed of typical hexagonal plates about $0.4-0.65 \mu \mathrm{m}$ in size (Figs. 5A, C).

Cells also have a pointed posterior end resembling the tail of Plagioselmis (Fig. 5C). However, unlike Plagioselmis the periplast plates present on the main portion of the cell body (Fig. 5A) also extend onto the tail (Fig. 5C). Hill (1992a) noted that a tail may be present also in Hemiselmis virescens Droop (1955), which Hemiselmis sp. inedit. somewhat resembles, but $H$. virescens lacks the characteristic ventral furrow of Hemiselmis sp. inedit., a structure which is hitherto undocumented in the genus Hemiselmis (Novarino and Lucas, 1993a). Additional differences between this species and other species of Hemiselmis include the size of the periplast plates, flagellar length, and flagellar/cell length ratio (Table 1).

Although the presence of a furrow makes this cryptomonad a unique representative of the genus Hemiselmis, this does not raise concerns if one accepts the view that furrows are taxonomically 


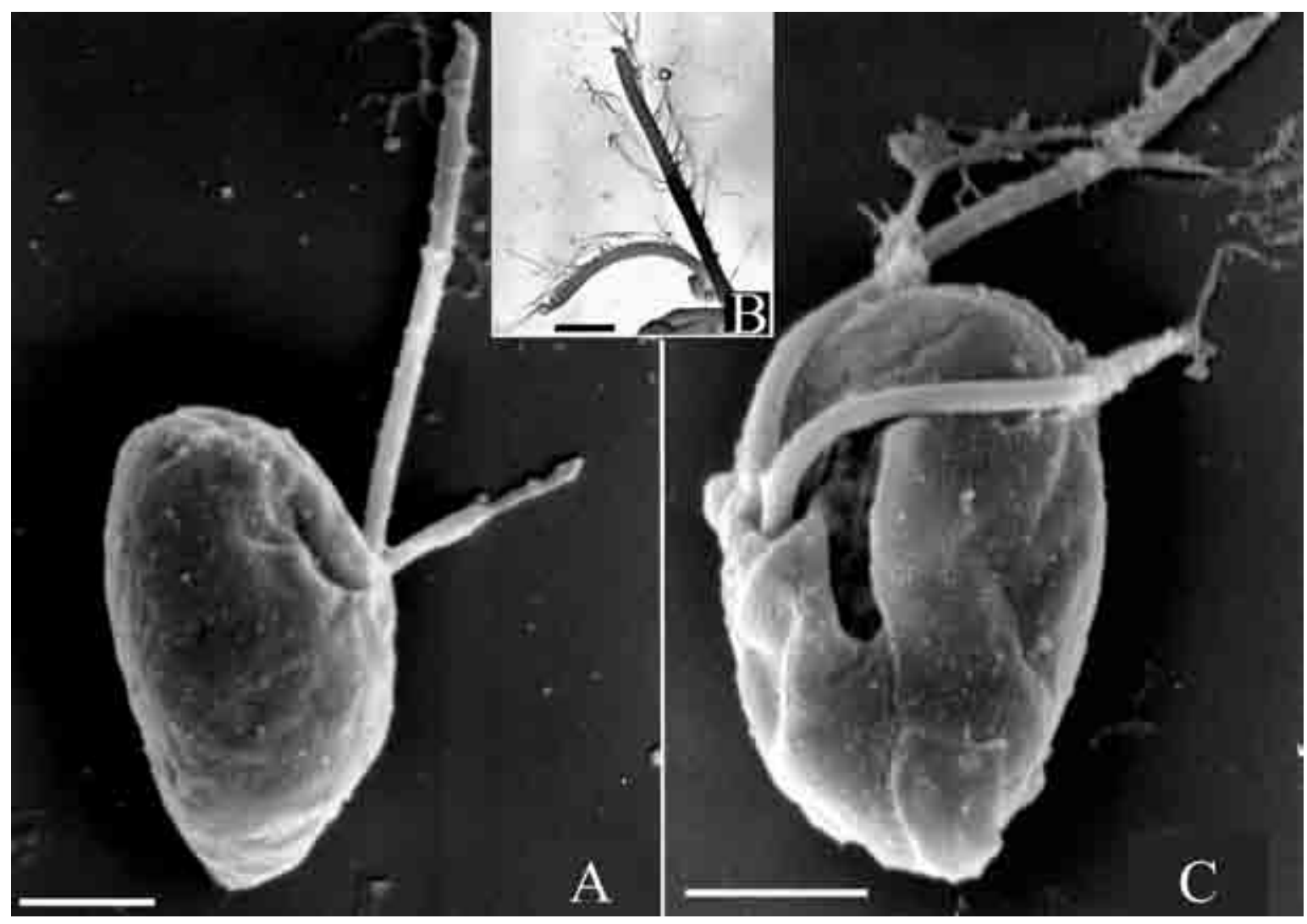

FIG. 5. - Hemiselmis sp. inedit. from the Mediterranean Sea, SEM, HMDS-dried material. A, a cell in lateral view. B, arrangement of flagellar mastigonemes (reverse print). C, this cell in ventral view shows the characteristic ventral furrow, which is displaced towards the left-hand side of the point of flagellar insertion. Scale bars $=1 \mu \mathrm{m}$.

TABLE 1. - Selected morphological features of some species of Hemiselmis.

\begin{tabular}{|c|c|c|c|c|c|}
\hline Species & Cell size $(\mu \mathrm{m})$ & Flagella & $\begin{array}{l}\text { Size of periplast } \\
\text { plates }(\mu \mathrm{m})\end{array}$ & Tail & $\begin{array}{l}\text { Furrow (as docu- } \\
\text { mented using SEM) }\end{array}$ \\
\hline $\begin{array}{l}\text { Hemiselmis amylosa } \\
\text { Clay and Kugrens }\end{array}$ & $5-6 \times 3-3.5 \times 2.5-3$ & $\begin{array}{l}\text { subequal, with the } \\
\text { longer (dorsal) one a } \\
\text { bout as long as the } \\
\text { cell }\end{array}$ & $\begin{array}{l}\text { ca. } 1-1.25 \\
\text { (estimate based on } \\
\text { Clay and Kugrens, 1999, } \\
\text { Fig. 13) }\end{array}$ & absent & absent \\
\hline $\begin{array}{l}\text { Hemiselmis brunnescens } \\
\text { Butcher }\end{array}$ & $5-5.5 \times 3 \times 2.5-3$ & unequal, 6-7 $\mu \mathrm{m}$ long & $\begin{array}{l}\text { ca. } 0.6 \text { (estimate based on } \\
\text { Wetherbee } \text { et al., 1986, } \\
\text { Fig. 8) }\end{array}$ & absent & $\begin{array}{l}\text { absent (Santore, 1982, } \\
\text { Fig. 1; Wetherbee } \text { et } \\
\text { al., 1986, Fig. 2) }\end{array}$ \\
\hline $\begin{array}{l}\text { Hemiselmis rufescens } \\
\text { Parke }\end{array}$ & $4-8.5 \times 3.5-5 \times 2-3$ & $\begin{array}{l}\text { unequal, the longer } \\
\text { (dorsal) one about } 1.5 \\
\text { times the cell length }\end{array}$ & $?$ & absent & $\begin{array}{l}\text { absent (Santore, } \\
\text { 1977, Fig. 4) }\end{array}$ \\
\hline Hemiselmis sp. inedit. & $3-4 \times 1.5-2$ & subequal-unequal & $0.4-0.65$ & present & present \\
\hline Hemiselmis sp. 1 & $3-5 \times 2-3$ & $\begin{array}{l}\text { equal, } 1 / 2 \text { to } 3 / 4 \text { the } \\
\text { cell length }\end{array}$ & $\begin{array}{l}\text { up to } 1.25 \mu \mathrm{m}(0.75 \mu \mathrm{m} \\
\text { on average })\end{array}$ & absent & absent \\
\hline Hemiselmis sp. 2 & $\begin{array}{l}2.5-4 \times 1.5-2.5 \text { (this } \\
\text { paper); 3.5-4.5 x } 2- \\
2.5 \text { (Novarino et al., } \\
1997 \text { ) }\end{array}$ & $\begin{array}{l}\text { slightly unequal, with } \\
\text { the longer (dorsal) one } \\
\text { slightly longer than } \\
\text { the cell }\end{array}$ & $0.4-0.7$ & absent & absent \\
\hline $\begin{array}{l}\text { Hemiselmis virescens } \\
\text { Droop }\end{array}$ & $\begin{array}{l}\text { 5-7 (Droop 1955); } \\
\text { 4.5-7 x 2.5-3 (Butcher, } \\
\text { 1967); 4-6 x } 3 \text { (Hill, } \\
\text { 1992a). }\end{array}$ & $\begin{array}{l}\text { slightly unequal, with } \\
\text { the longer (dorsal) one } \\
\text { slightly longer than the } \\
\text { cell (Droop, 1955); uneq } \\
\text { (Butcher, 1967); equal, a } \\
\text { long as the cell (Hill, } 199\end{array}$ & $\begin{array}{l}? \\
\text { aual } \\
\text { as } \\
92 \mathrm{a}) \text {. }\end{array}$ & $\begin{array}{l}\text { occasionally } \\
\text { present } \\
\text { (Hill 1992a) }\end{array}$ & absent \\
\hline
\end{tabular}




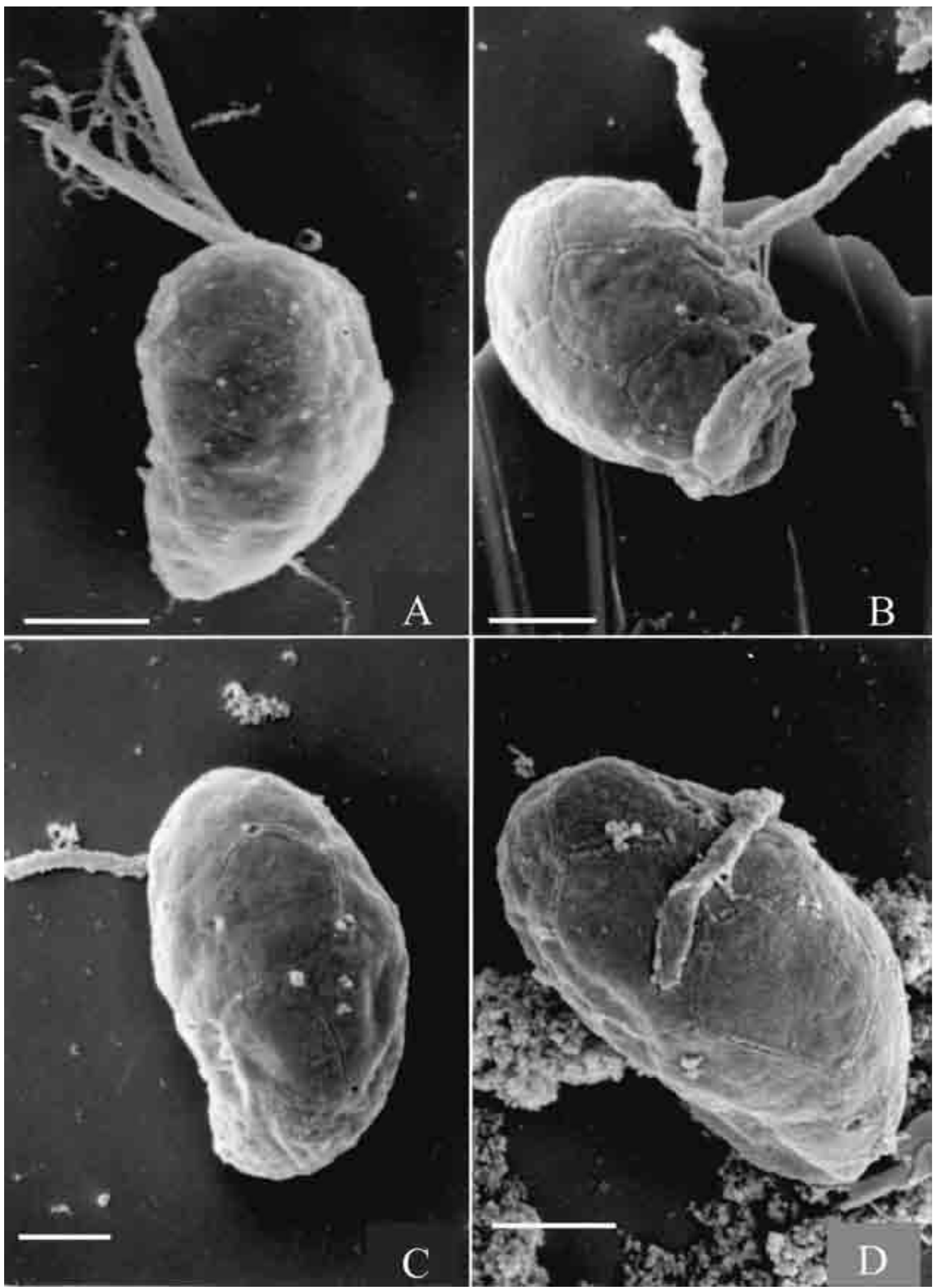

Fig. 6. - Hemiselmis sp. 1 from the Mediterranean Sea, SEM, HMDS-dried material. A, a cell in dorso-lateral view. B, a cell in lateral view seen from the posterior end. C, D, two cells in dorsal view, showing the variability of the size of the periplast plates. Scale bars $=1 \mu \mathrm{m}$. 
significant at the specific level (Novarino, 1991b; Novarino et al., 1994). However, if the view is followed that furrows have a generic value (Clay et al., 1999), then it could be asked if this cryptomonad should be assigned to a different genus. The simultaneous presence of a furrow which is displaced towards the left-hand side of the point of flagellar insertion, and a periplast composed of hexagonal plates, is also found in members of the genus Plagioselmis (Novarino et al., 1994) and Falcomonas Hill, a monospecific genus characterised by the presence of a unique phycocyanin pigment (Hill, 1991b; Clay and Kugrens, 1999). However, in both those genera the typical size of the periplast plates is smaller than in Hemiselmis sp. inedit., and therefore there are considerably

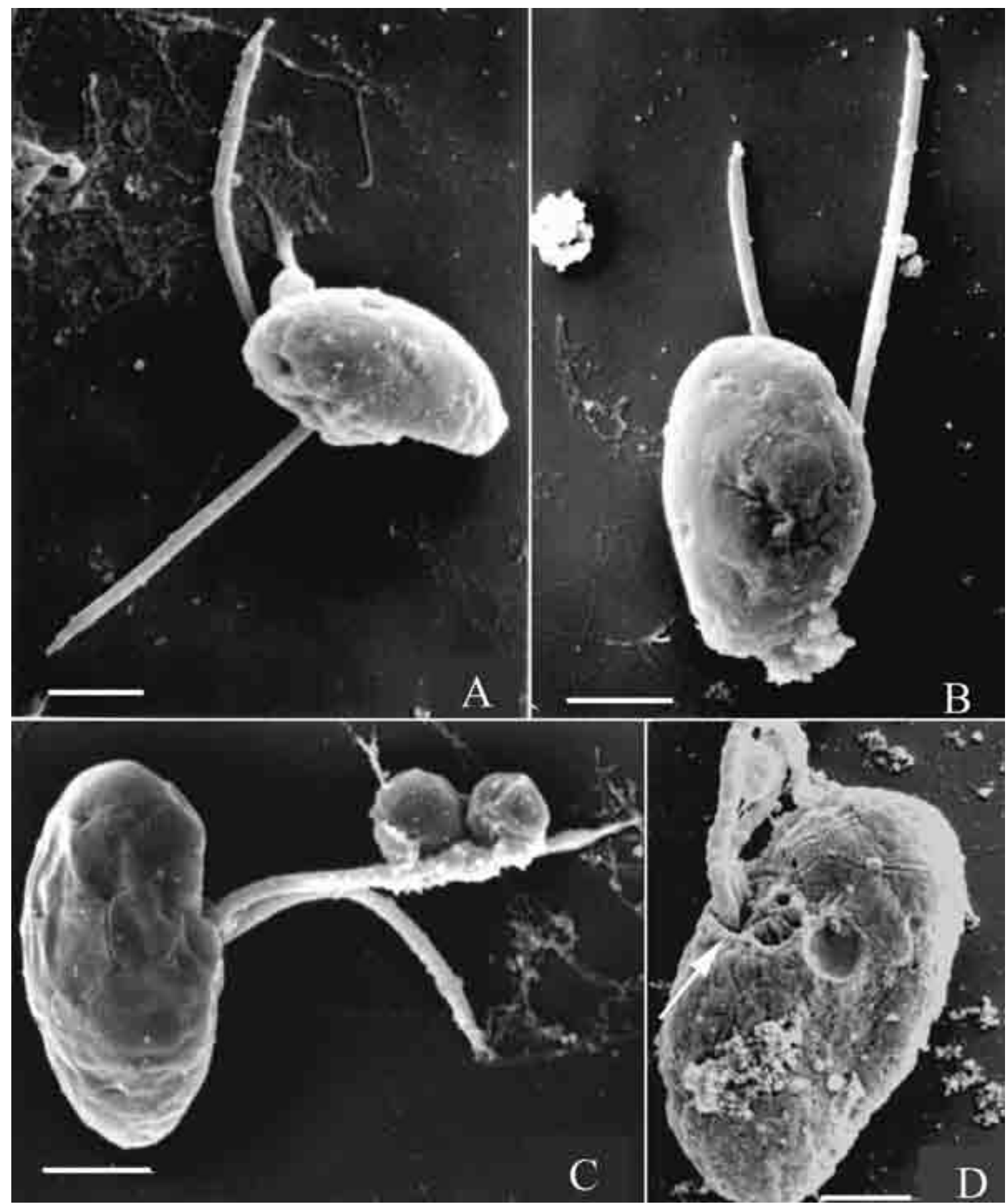

FIG. 7. - Hemiselmis sp. 2 from the Mediterranean Sea, SEM, HMDS-dried material. A, a cell in dorso-lateral view. B, a cell in dorsal view. $\mathbf{C}$, a cell in ventro-lateral view. $\mathbf{D}$, a cell in ventral view; note that a ventral furrow at the point of flagellar iinsertion (arrow) is absent (compare Hemiselmis sp. inedit., Fig. 5C). Scale bars $=1 \mu \mathrm{m}$. 
more plates per cell in Plagioselmis and Falcomonas than in Hemiselmis sp. inedit. Furthermore, cells of Hemiselmis sp. inedit. are considerably smaller than is typical in Plagioselmis and Falcomonas. In any case the identity of the phycobilin pigment of Hemiselmis sp. inedit. is unknown, making it impossible to verify whether or not this cryptomonad might be better placed in Falcomonas, but this is probably unlikely. As mentioned, the kind of periplast present on the posterior tail of Hemiselmis sp. inedit. clearly sets it apart from Plagioselmis. It cannot be excluded that this cryptomonad effectively represents an hitherto undescribed genus, but further information (phycobilin pigment, internal ultrastructure, and probably molecular sequence data) is necessary in order to verify this possibility. Further insight into the systematic position of this cryptomonad will require the establishment of monospecific cultures.

This cryptomonad was found in the Sea of Alboran stations $A$ and $C$ at depths between 40 and $70 \mathrm{~m}$, i.e. below the deep chlorophyll maxima, which were located between 30 and $44 \mathrm{~m}$. It also occurred in two time series samples from the port of Barcelona.

\section{Hemiselmis sp. 1 (Fig. 6)}

Known geographical distribution: So far known only from the Sea of Alboran and port of Barcelona.

Cells of Hemiselmis sp. 1 (Fig. 6) are about 3-5 $\mu \mathrm{m}$ long and 2-3 $\mu \mathrm{m}$ thick. There are two equal flagella about 1/2 - 3/4 the cell length (Figs. 6A, B). The flagella are inserted in a median (Fig. 6B) or subapical (Fig. 6A) position. There is no ventral furrow and no posterior tail. The periplast (Fig. 6C) is composed of typical, large hexagonal plates (size up to about $1.25 \mu \mathrm{m}$, about $0.75 \mu \mathrm{m}$ on average). Differences with other species of Hemiselmis are summarised in Table 1. Although there are similarities with previously described species of Hemiselmis, Hemiselmis sp. 1 cannot be identified as belonging to any one of them. However, owing to the relative scarcity of specimens in the examined samples a new species is not established for the time being.

Hemiselmis sp. 1 was found in the Sea of Alboran stations $\mathrm{CN}$ (Almeria-Oran front) and $\mathrm{C}$ at depths of 33 and $50 \mathrm{~m}$, i.e. at or below the deep chlorophyll maxima, which were located at 33 and $44 \mathrm{~m}$. It also occurred in three time series samples from the port of Barcelona.
Hemiselmis sp. 2 Novarino, Mills et Hannah

(Fig. 7)

Novarino et al., 1997, p. 1094, Fig. 5c.

Known geographical distribution: North Sea (Novarino et al., 1997); Mediterranean Sea: Sea of Alboran, port of Barcelona.

Cells of Hemiselmis sp. 2 Novarino et al. (1997) from the Mediterranean Sea (Fig. 7) are about 2.5-4 $\mu \mathrm{m}$ long and 1.5-2.5 $\mu \mathrm{m}$ thick, and therefore smaller than those described previously from the North Sea (Novarino et al., 1997). There are two slightly unequal flagella, of which the longer (dorsal) one is slightly longer than the cell. The flagella are inserted in a median position (Fig. 7C) and there is no furrow. The periplast is composed of typical hexagonal plates (Fig. 7C), on average about $0.5 \mu \mathrm{m}$ in size and ranging between 0.4 and $0.7 \mu \mathrm{m}$. Differences with other species of Hemiselmis are summarised in Table 1. Analogous to Hemiselmis sp. 1, a new species is not established for the time being.

Hemiselmis sp. 2 was found in the Sea of Alboran station $\mathrm{C}$ at a depth of $50 \mathrm{~m}$, i.e. below the deep chlorophyll maximum, which was located at $35 \mathrm{~m}$. It also occurred in two time series samples from the port of Barcelona.

Genus Plagioselmis Butcher emend. Novarino Lucas et Morrall $(\mathrm{ICBN})=$ Plagioselmis Butcher (ICZN)

Butcher, 1967, Fishery Investigations, London, Series IV, p. 18, pl. I Figs. 9, 10, pl. XIV Figs. 2, 3. Emend. Novarino, Lucas and Morrall, 1994, Cryptogamie-Algologie Vol. 15, p. 90, Figs. 1-26.

Lectotype species: Plagioselmis prolonga Butcher ex Novarino Lucas and Morrall, 1994, p. 90, Figs. 1-18. (ICBN); nomenclatural equivalent: Plagioselmis prolonga Butcher, 1967, p. 18, pl. I Fig. 9, pl. XIV Fig. 2 (ICZN); synonym (ICBN): Plagioselmis prolonga Butcher, 1967, p. 18, pl. I Fig. 9, pl. XIV Fig. 2, typ. non desig.

\section{Key to the species found here:}

1. Furrow absent P. nordica

- Furrow present. 2

2. Periplast plates large (on average about $0.4 \mu \mathrm{m}$ ); tail about $1 / 7-1 / 3$ the cell length; mid-ventral band present on the tail and extending to the base of the ventral furrow P. prolonga

- Periplast plates smaller $(0.2-0.3 \mu \mathrm{m})$; tail about $1 / 10$ the cell length; mid-ventral band present on the tail only, i.e. it does not extend to the base of the furrow $P$. sp. inedit 


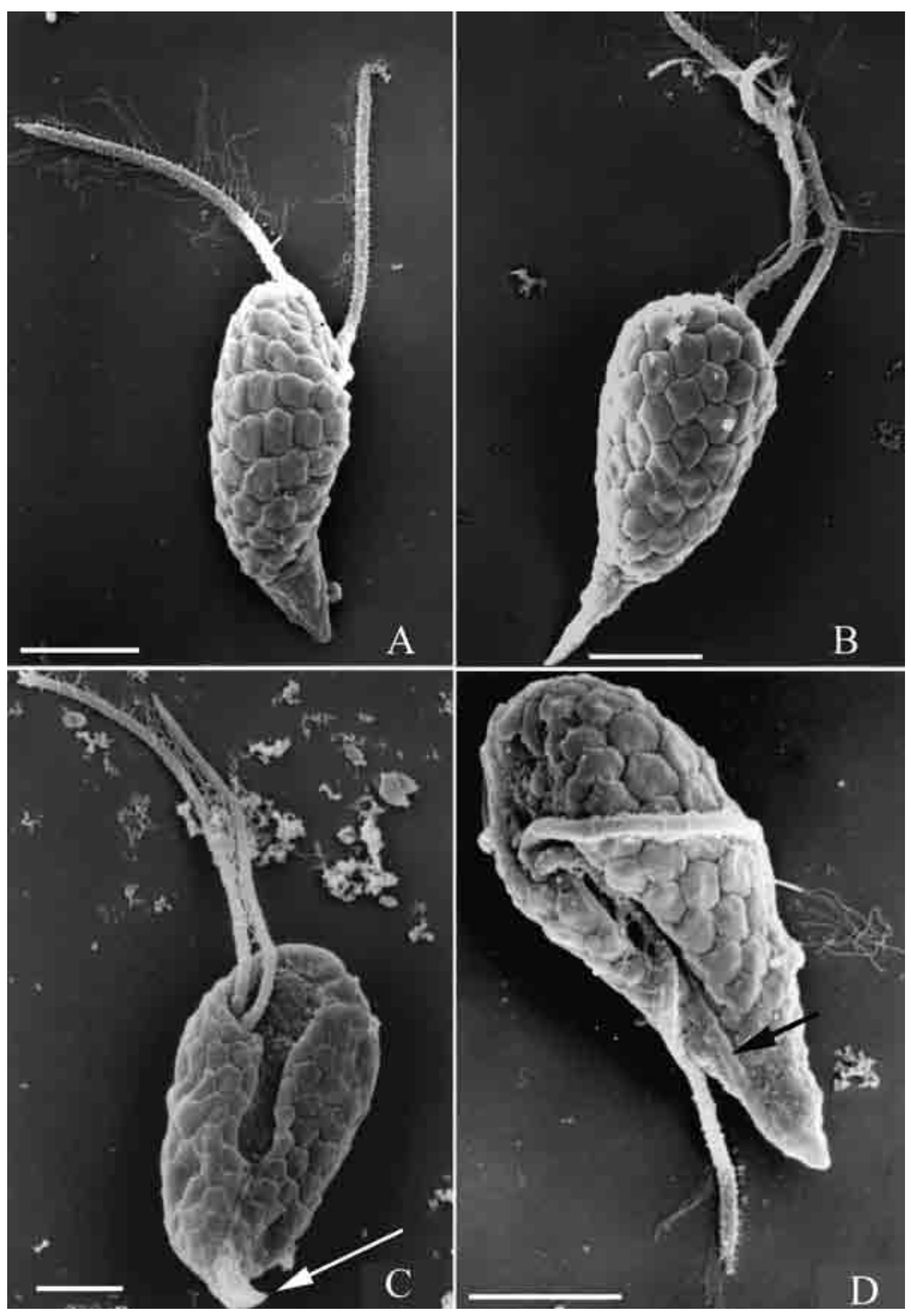

FIG. 8. - Plagioselmis prolonga from the Mediterranean Sea, SEM, HMDS-dried material. A, a cell in lateral view, showing the typical flagellar ornamentation. B, a cell in dorsal view. C, a cell in ventral view, showing the characteristic furrow. D, another cell in ventral view; note that the mid-ventral band (arrow) extends to the base of the furrow. Scale bars $=2 \mu \mathrm{m}$. 
Plagioselmis prolonga Butcher ex Novarino, Lucas et Morrall $(\mathrm{ICBN})=$ Plagioselmis prolonga Butcher (ICZN) (Figs. 2, 8)

Butcher, 1967, pl. I Fig. 9, pl. XIV Fig. 2; Novarino et al., 1994, p. 90, Figs. 1-18.

Synonym (ICBN): Plagioselmis prolonga Butcher, 1967, pl. I Fig. 9, pl. XIV Fig. 2, typ. non desig.; Hill, 1992b, p. 165, Figs. 1 A - P; Kuylenstierna and Karlson, 1994, p. 22, Figs. 8a, b.

Lectotype (ICBN): Butcher, 1967, pl. I Fig. 9 (designated by Novarino et al., 1994); nomenclatural equivalent: Plagioselmis prolonga Butcher, 1967, p. 18, pl. I Fig. 9, pl. XIV Fig. 2 (ICZN).

Allied taxa: Plagioselmis prolonga forma japonica Throndsen, 1983, p. 5, Fig. 11; Plagioselmis sp. 'B' Throndsen, 1983, p. 5, Figs. 9, 10; Plagioselmis punctata Butcher, 1967, p. 19, pl. I Fig. 10, pl. XIV Fig. 3; Chroomonas sp. Andreoli et al., 1986, Figs. 16; Chroomonas sp. Bisalputra et al., 1973, Fig. 14; Cryptomonas sp. Booth et al., 1982, Fig. 21; Cryptomonas sp. Delgado and Fortuño, 1991, p. 22, pl. XC c.

Known geographical distribution: Mediterranean Sea: Sea of Alboran, Barcelona coastal waters, port of Barcelona; Northern Atlantic: British coastal waters (Butcher, 1967), Irish Sea (Novarino, unpublished), oyster basins south of La Rochelle, France (Billard, personal communication, and Novarino, unpublished), Baltic Sea (Hill, 1992b), Skagerrak (Kuylenstierna and Karlson, 1994).

Cells of Plagioselmis prolonga from the Mediterranean Sea (Figs, 2, 8) are about 6-10 $\mu \mathrm{m}$ long and 2.5-4.5 $\mu \mathrm{m}$ thick. There are two subequal flagella, of which the longer (dorsal) one is about as long as the cell (Fig. 8A). In glutaraldehyde-fixed material, the typical flagellar ornamentation of this species is clearly visible (Fig. 8A); it consists of the usual double row of tubular hairs on the dorsal flagellum and a single row on the ventral one, with additional short, fibrillar hairs on both flagella. The flagella are inserted in a subapical position, and to the left-hand side of the point of flagellar insertion there is a ventral furrow which extends to the median part of the cell but not considerably beyond it (Figs. 8C, D). As is typical in this genus, the pointed posterior tail carries a sheet-like periplast instead of the hexagonal plates present on the main portion of the cell body (Figs. 2, 8). The tail is variable in shape (e.g. 8A, a blade-like tail; Fig. 8C, a pointed, ventrally curved tail) and length, but not shorter than about $1 / 7$ the cell length. It carries a distinct midventral band, which extends towards and reaches the base of the ventral furrow (Figs. 8C, D). On average the periplast plates on the main portion of the cell body are about $0.4 \mu \mathrm{m}$ in size. Plagioselmis prolon$g a$ is easily distinguished from other species of its genus (Table 2).

Plagioselmis prolonga was found in the majority of samples from the Sea of Alboran, the Barcelona transect and the port of Barcelona, at all depths, and the morphology of the specimens closely matched that reported in the emended description (Novarino et al., 1994). This, together with the fact that P. prolonga has been reported from a variety of geographical regions, confirms that this species has a wide distribution, at least as far as can be judged based on morphology alone. It is not known whether or not this wide distribution of morphologically homogeneous populations conceals a number of genetically or physiologically distinct entities.

Plagioselmis nordica stat. nov. $(\mathrm{ICBN})=$ Plagioselmis nordica sp. nov. (ICZN) (Fig. 9)

Synonym (ICBN): Plagioselmis prolonga var. nordica Novarino et al., 1994, p. 92, Figs. 19 (holotype), 20 (paratype); Novarino et al., 1997, p. 1096, Fig. 15; Bérard-Therriault et al., 1999, p. 249, pl. 115a-f, j. Plagioselmis sp. Novarino, 1991b, p. 602, Figs. 3, 4.

Diagnosis (ICZN): A small Plagioselmis without a ventral furrow.

Holotype (ICZN): Novarino et al., 1994, Fig. 19, from a plankton sample from the southern North Sea collected on 8/8/1988 at $4 \mathrm{~m}$

TABLE 2. - Selected morphological features of marine species of Plagioselmis.

\begin{tabular}{|c|c|c|c|c|c|c|}
\hline Species & Cell size $(\mu \mathrm{m})$ & Flagella & $\begin{array}{l}\text { Size of periplast } \\
\text { plates }(\mu \mathrm{m})\end{array}$ & Tail & Furrow & Mid-ventral band \\
\hline$P$. sp. inedit. & $6-9 \times 4-5.5 \times 3-4$ & $\begin{array}{l}\text { equal - subequal, } \\
\text { about } 1 / 3 \text { to } 3 / 3 \text { the } \\
\text { cell length }\end{array}$ & $0.15-0.25$ & $\begin{array}{l}1 / 10 \text { the cell } \\
\text { length }\end{array}$ & $\begin{array}{l}\text { present, extends } \\
\text { to about } 2 / 3 \text { the } \\
\text { cell length }\end{array}$ & $\begin{array}{l}\text { present, does not } \\
\text { extend from the tail } \\
\text { towards the furrow }\end{array}$ \\
\hline P. nordica & $4-6 \times 2-3$ & $\begin{array}{l}\text { subequal, the longer } \\
\text { (dorsal) one about } 1 \\
\text { to } 1.5 \text { times the cell } \\
\text { length }\end{array}$ & $0.25-0.4$ & $\begin{array}{l}1 / 5 \text { to } 1 / 4 \text { the } \\
\text { cell length }\end{array}$ & absent & absent \\
\hline P. prolonga & $6-10 \times 2.5-4.5$ & $\begin{array}{l}\text { subequal, the longer } \\
\text { (dorsal) one about as } \\
\text { long as the cell }\end{array}$ & 0.4 & $\begin{array}{l}1 / 7 \text { to } 1 / 3 \text { the } \\
\text { cell length }\end{array}$ & $\begin{array}{l}\text { present, extends } \\
\text { to about } 1 / 2 \\
\text { the cell length }\end{array}$ & $\begin{array}{l}\text { present, extends } \\
\text { from the tip of } \\
\text { the tail to the } \\
\text { base of the furrow }\end{array}$ \\
\hline
\end{tabular}



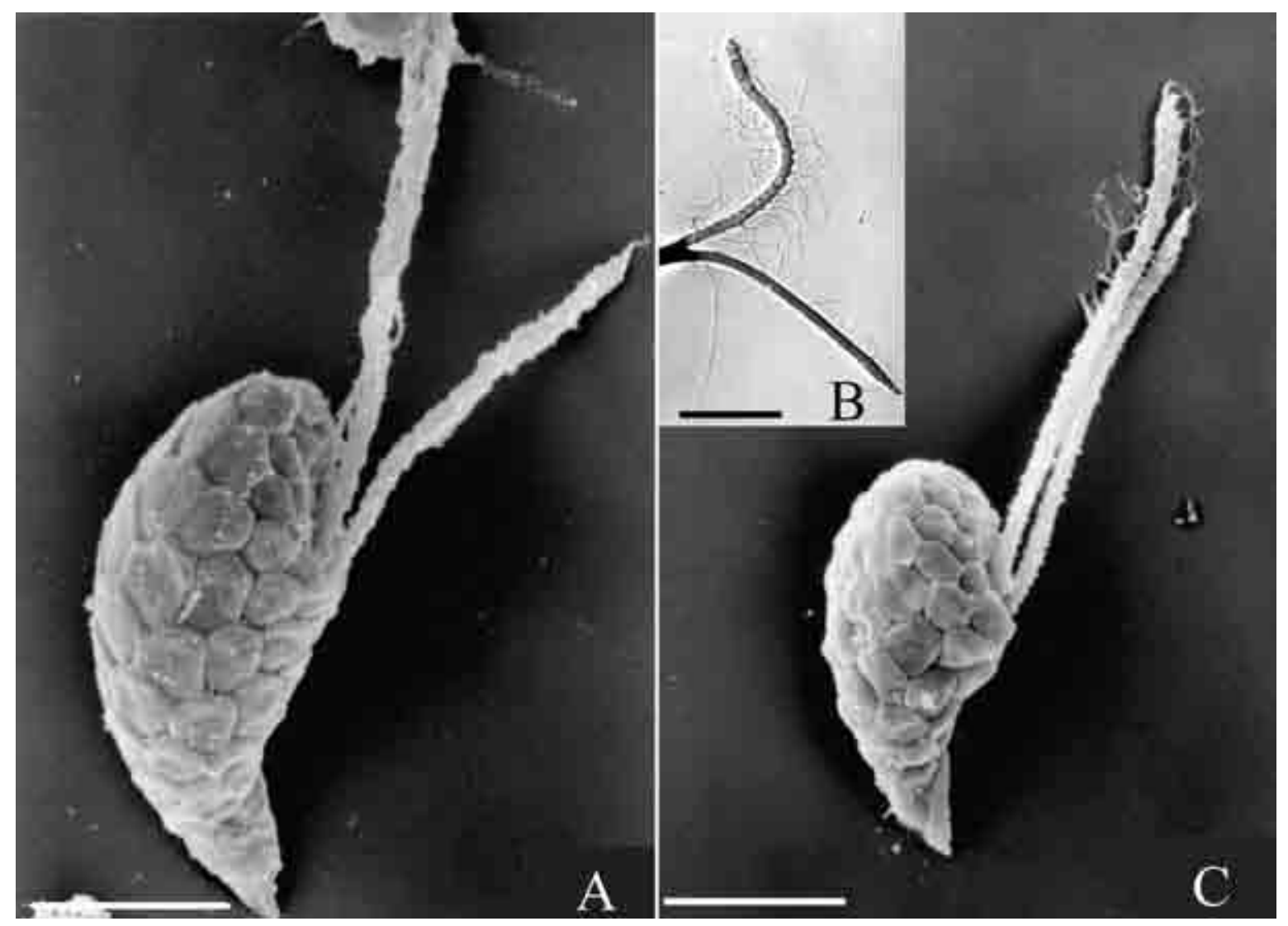

FIG. 9. - Plagioselmis nordica from the Mediterranean Sea, SEM, HMDS-dried material. A, a cell in ventro-lateral view; note the absence of a ventral furrow. B, arrangement of flagellar mastigonemes (reverse print). C, a cell in lateral view. Scale bars $=2 \mu \mathrm{m}$.

depth from station BG during cruise no. 33 of the UK Natural Environment Research Council (NERC) North Sea Community Project $1988 / 89$.

Allied taxa: Plagioselmis sp. "A" Throndsen, 1983, p. 5, Figs. 7, 8. Cryptomonas acuta sensu Chang, 1983, Fig. 7A, non Cryptomonas acuta Butcher, 1952, p. 188, pl. 2 Figs. 51-53.

Known geographical distribution: Mediterranean Sea: Sea of Alboran; Northern Atlantic: southern North Sea (Novarino et al., 1997), St. Lawrence estuary and gulf (Bérard-Therriault et al., 1999).

Cells of Plagiosemis nordica from the Mediterranean Sea (Fig. 9) are about 4 - $6 \mu \mathrm{m}$ long and 2 $3 \mu \mathrm{m}$ thick. There are two subequal flagella, of which the longer (dorsal) one is about 1 to 1.5 times the cell length (Fig. 9A, C). As in P. prolonga, the flagella appear to carry short fibrillar hairs (Fig. 9C) in addition to the usual double row of tubular hairs on the dorsal flagellum and single row on the ventral one (Fig. 9B). Another similarity with P. prolonga is that the flagella are inserted subapically (Fig. 9C). However, unlike $P$. prolonga the point of flagellar insertion is not displaced towards the right-hand side of the cell (Fig. 9A), and a ventral furrow is absent.
The morphology of the tail is similar to that of $P$. prolonga. The Mediterranean specimens of $P$. nordi$c a$ have a tail about $1 / 4$ to $1 / 2$ the cell length, while in the type material from the North Sea (Novarino et $a l ., 1994)$ the tail is about $1 / 5$ the cell length. In the Mediterranean specimens the average size of the hexagonal periplast plates on the main portion of the cell body is about $0.4 \mu \mathrm{m}$, compared to about $0.3 \mu \mathrm{m}$ in the type material (Novarino et al., 1994).

Plagioselmis nordica was found in the Sea of Alboran station $\mathrm{C}$ at a depth of $50 \mathrm{~m}$, i.e. below the deep chlorophyll maximum, which was located at $44 \mathrm{~m}$.

Note on taxonomy and nomenclature. This cryptomonad was first described under the ICBN only, as a variety of Plagioselmis prolonga, i.e. P. prolonga var. nordica (Novarino et al., 1994). Now that more information and further reports are available, there is sufficient morphological evidence to raise the status of $P$. prolonga var. nordica to that of a species under the ICBN. Although this status change introduces nomenclatural instability, it is advantageous from the point of view of ambiregnal nomen- 
clature because infraspecific taxa at the variety level are not regulated by the ICZN, and therefore P. prolonga var. nordica has no standing under the zoological nomenclature. Therefore, under the ICZN we describe $P$. nordica as a new species to all effects, and a formal diagnosis is required together with the designation of a holotype. For the sake of consistency across the Codes of nomenclature, the ICZN holotype designated here is identical to that already designated under the ICBN (Novarino et al., 1994).

\section{Plagioselmis sp. inedit.} (Figs. 10, 14C)

Known geographical distribution: So far known only from the Sea of Alboran.

Cells of Plagioselmis sp. inedit. (Figs. 10, 14C) have a broadly rounded (Fig. 10C) or, less frequently, slightly rostrate (Fig. 10A) anterior end, and are slightly compressed along the perlateral axis. They are about 6-9 $\mu \mathrm{m}$ long, 4-5.5 $\mu \mathrm{m}$ thick, and 3-4 $\mu \mathrm{m}$ wide. There are two equal (Fig. 10A) or slightly unequal (Fig. 10C) flagella, ranging in length from about $1 / 3$ the cell length to cell length. The flagella are inserted in a subapical position, and to the left-hand side of the point of flagellar insertion there is a broad ventral furrow extending to about $2 / 3$ the cell length (Fig. 10C). The tail (Fig. 10C) is about 1/10 the cell length and therefore very short compared to other species of Plagioselmis. The mid-ventral band is present on the tail only and it does not extend towards the base of the furrow (Fig. 10C). The periplast is composed of small, barely perceptible hexagonal plates about $0.15-0.25$ $\mu \mathrm{m}$ in size (Fig. 10B).

Table 2 gives a comparison of this cryptomonad with other species of Plagioselmis. Plagioselmis sp. inedit. is very unusual owing to its very short tail and mid-ventral band, and the small size of the periplast plates. The plates may be difficult to detect in the SEM and therefore the periplast may superficially appear to be sheet-like, in which case Plagioselmis sp. inedit. may be mistaken for Teleaulax amphioxeia, which it resembles in general morphology (see below). However, these two cryptomonads

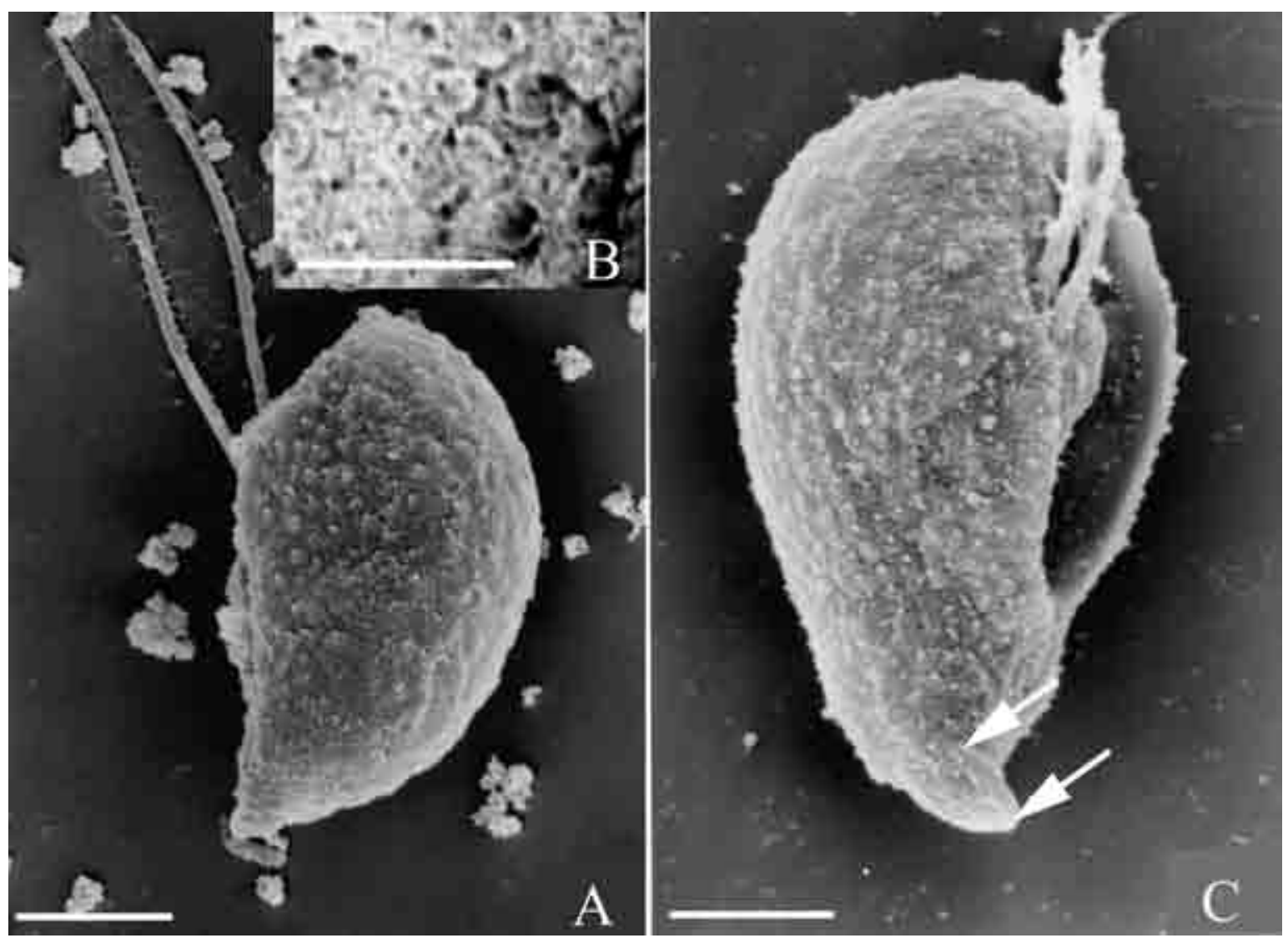

FIG. 10. - Plagioselmis sp. inedit. from the Mediterranean Sea, SEM, HMDS-dried material. A, a cell in lateral view. B, detail of the very small hexagonal periplast plates (photographic enlargement, reverse print). C, a cell in ventral view; showing the characteristic, broad ventral furrow extending well beyond the middle region of the cell and the very short tail carrying a very short mid-ventral band not extending to the base of the furrow (arrows). Scale bars $=2 \mu \mathrm{m}(\mathrm{A}, \mathrm{C})$ or $1 \mu \mathrm{m}(\mathrm{B})$. 


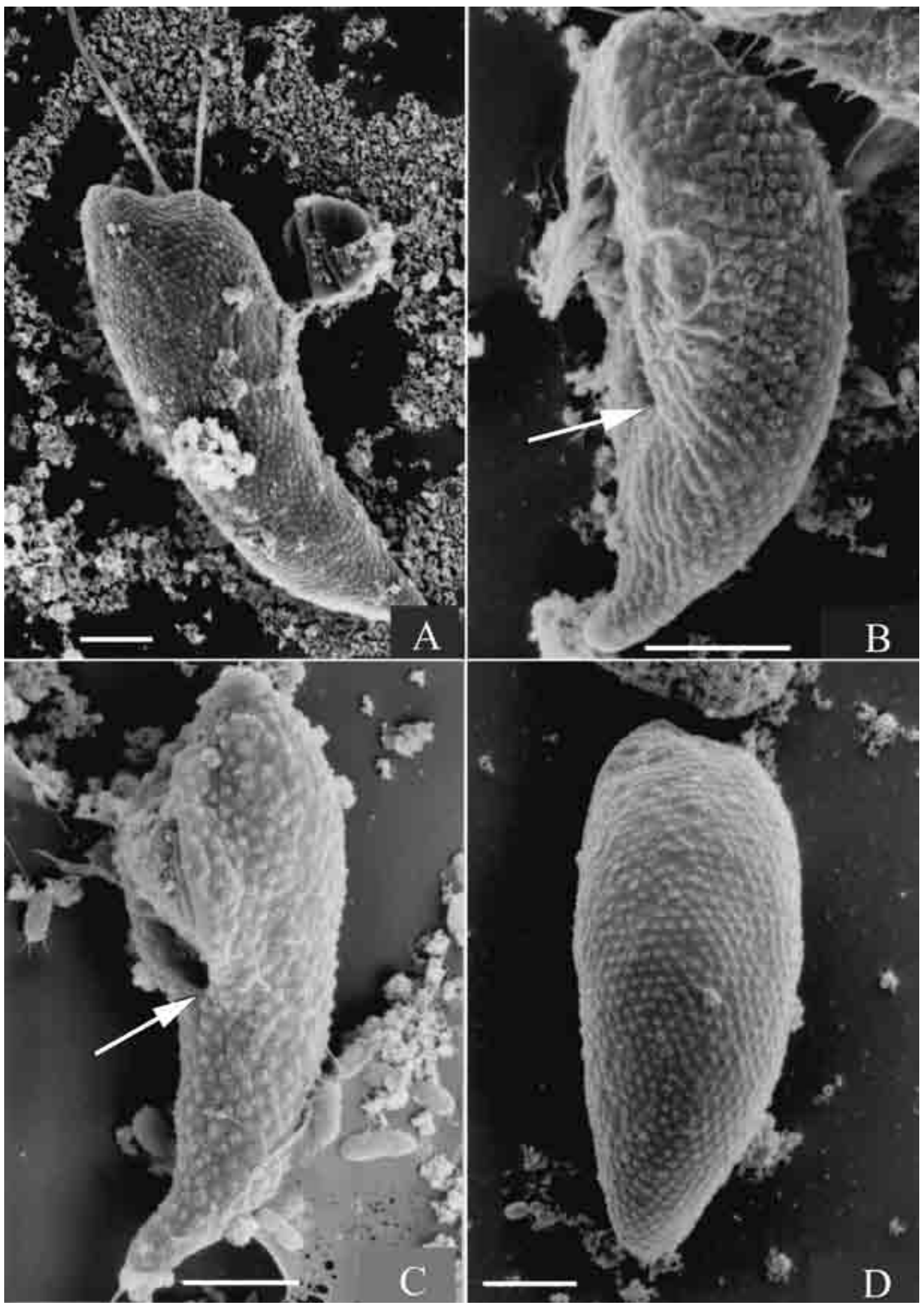

FIG. 11. - Teleaulax acuta from the Mediterranean Sea, SEM, HMDS-dried material. A, a cell in lateral view. B, C, two cells in ventro-lateral view, with furrows of different lengths (arrows). D, a cell in dorsal view; note the papillate appearance of the periplast, produced by the bulging ejectosomes present underneath the continuous, sheet-like periplast layer. Scale bars $=2 \mu \mathrm{m}$. 
can be told apart thanks to the mid-ventral band (absent in Teleaulax as a whole) and the fact that in Plagioselmis sp. inedit. the longer flagellum is the dorsal one while in T. amphioxeia it is the ventral one. There are also some resemblances with the phycocyanin-containing cryptomonad Falcomonas daucoides (pointed cell posterior, presence of a furrow and a mid-ventral band, and small hexagonal periplast plates: Hill, 1991b; Clay and Kugrens, 1999). However, unlike Plagioselmis as a whole Falcomonas daucoides has a tail periplast identical to the periplast found on the main portion of the cell body, i.e. both the tail and the cell body periplast are composed of hexagonal plates. In spite of the unique features of Plagioselmis sp. inedit a new taxon is not established for it at this stage because further ultrastructural information is necessary.

This cryptomonad was found in the Sea of Alboran stations $\mathrm{A}$ and $\mathrm{C}$ at depths of 5 and $50 \mathrm{~m}$, i.e. above or below the deep chlorophyll maxima, which were located at 30 and $35 \mathrm{~m}$.

\section{Genus Teleaulax Hill (ICBN, ICZN)}

Hill 1991, Phycologia vol. 30, p. 177, Figs. 6, 16-24, 25, 26.

Type species: Teleaulax acuta (Butcher) Hill, 1991a, p. 177, Figs. 6, 16-24; basionym: Cryptomonas acuta Butcher, 1952, p. 188, pl. II, Figs. 51-53.

\section{Key to the species found here}

1. Flagella equal or subequal; ventral furrow not displaced with respect to the point of flagellar insertion T. acuta

- Flagella unequal, with the ventral flagellum distinctly longer than the dorsal one; ventral furrow displaced to the left-hand side of the point of flagellar insertion T. amphioxeia

\section{Teleaulax acuta (Butcher) Hill (ICBN, ICZN)} (Fig. 11)

Hill, 1991a, p. 177, Figs. 6, 16-24; Hill, 1992c, 173-174, Figs. 1AM; Bérard-Therriault et al., 1999, p. 250, pl. 116e.

Basionym: Cryptomonas acuta Butcher 1952, p. 188, pl. 2 Figs. 5153; Novarino, 1991b, p. 602, Figs. 1, 2; Novarino et al., 1997, p. 1094, Fig. 13. Non Cryptomonas acuta sensu Chang, 1983, Fig. 7A.

Known geographical distribution: Mediterranean Sea: Sea of Alboran, port of Barcelona; Northen Atlantic: River Crouch and Conway, UK (Butcher, 1952), Baltic Sea (Hill, 1992c), Southern North Sea (Novarino et al., 1997), St. Lawrence estuary and gulf (Bérard-Therriault et al., 1999); Victoria, Australia (Hill, 1991a).

Cells of Teleaulax acuta from the Mediterranean Sea (Fig. 11) are about 9-16 $\mu \mathrm{m}$ long and 3.5-5 $\mu \mathrm{m}$ thick. There are two equal flagella about $1 / 4$ to $1 / 2$ the cell length (Figs. 11A, B). The flagella are inserted at the upper end of a ventral furrow (Fig. 11B) which extends to about $1 / 4-1 / 2$ the cell length (Figs. 11B, C). Owing to their characteristically acute posterior end (Figs. 11B, C), the cells superficially resemble Plagioselmis. However, T. acuta can be identified unequivocally thanks to its sheet-like

TABLE 3. - Selected morphological features of Teleaulax acuta from various geographical localities.

\begin{tabular}{|c|c|c|c|c|}
\hline Geographical locality & $\begin{array}{l}\text { Cell size ( } \mu \mathrm{m}, \text { mean } \\
\text { values in brackets) }\end{array}$ & Flagella & Furrow & References \\
\hline $\begin{array}{l}\text { River Crouch and Conway, } \\
\text { U.K. }\end{array}$ & $12-15 \times 4-6 \times 5-7$ & subequal, $12-15 \mu \mathrm{m}$ long & $\begin{array}{l}\text { "dies out almost at } \\
\text { the base" }\end{array}$ & $\begin{array}{l}\text { Butcher, } 1952 \text { (original } \\
\text { description of } \\
\text { Cryptomonas acuta) }\end{array}$ \\
\hline Southern North Sea & up to 14 (ca. 8) x 3 & subequal, about cell length & $\begin{array}{l}\text { extends to } 1 / 2-2 / 3 \\
\text { cell length }\end{array}$ & $\begin{array}{l}\text { Novarino, 1991b, } \\
\text { Novarino et al., } 1997 \\
\text { (as Cryptomonas acuta) }\end{array}$ \\
\hline Victoria, Australia & $\begin{array}{l}\text { ca. } 11 \text { x } 6.5 \text { (from SEM } \\
\text { micrograph, Fig. } 17 \text { ) }\end{array}$ & $?$ & $\begin{array}{l}\text { "runs almost the } \\
\text { length of the cells" } \\
\text { (p. 177); about } 2 / 3 \text { cell } \\
\text { length (Fig. 17) }\end{array}$ & Hill, 1991a \\
\hline Baltic Sea & $12-18 \times 5-8$ & $\begin{array}{l}\text { "subequal, slightly shorter } \\
\text { than the cell"" }\end{array}$ & $\begin{array}{l}\text { "extends almost to } \\
\text { the posterior" }\end{array}$ & Hill, 1992c \\
\hline St. Lawrence estuary and gulf & $11-18(15)$ x 4.8-8.8 (6.6) & $12-22(15) \mu \mathrm{m}$ long & $\begin{array}{l}\text { extends to } 3 / 4 \text { cell } \\
\text { length }\end{array}$ & $\begin{array}{l}\text { Bérard-Therriault et al., } \\
1999\end{array}$ \\
\hline Mediterranean Sea & $9-16(12) \times 3.5-5(4.25)$ & $\begin{array}{l}\text { equal, } 1 / 4 \text { to } 1 / 2 \text { cell } \\
\text { length }\end{array}$ & $\begin{array}{l}\text { extends to } 1 / 2-2 / 3 \\
\text { cell length }\end{array}$ & This paper \\
\hline
\end{tabular}



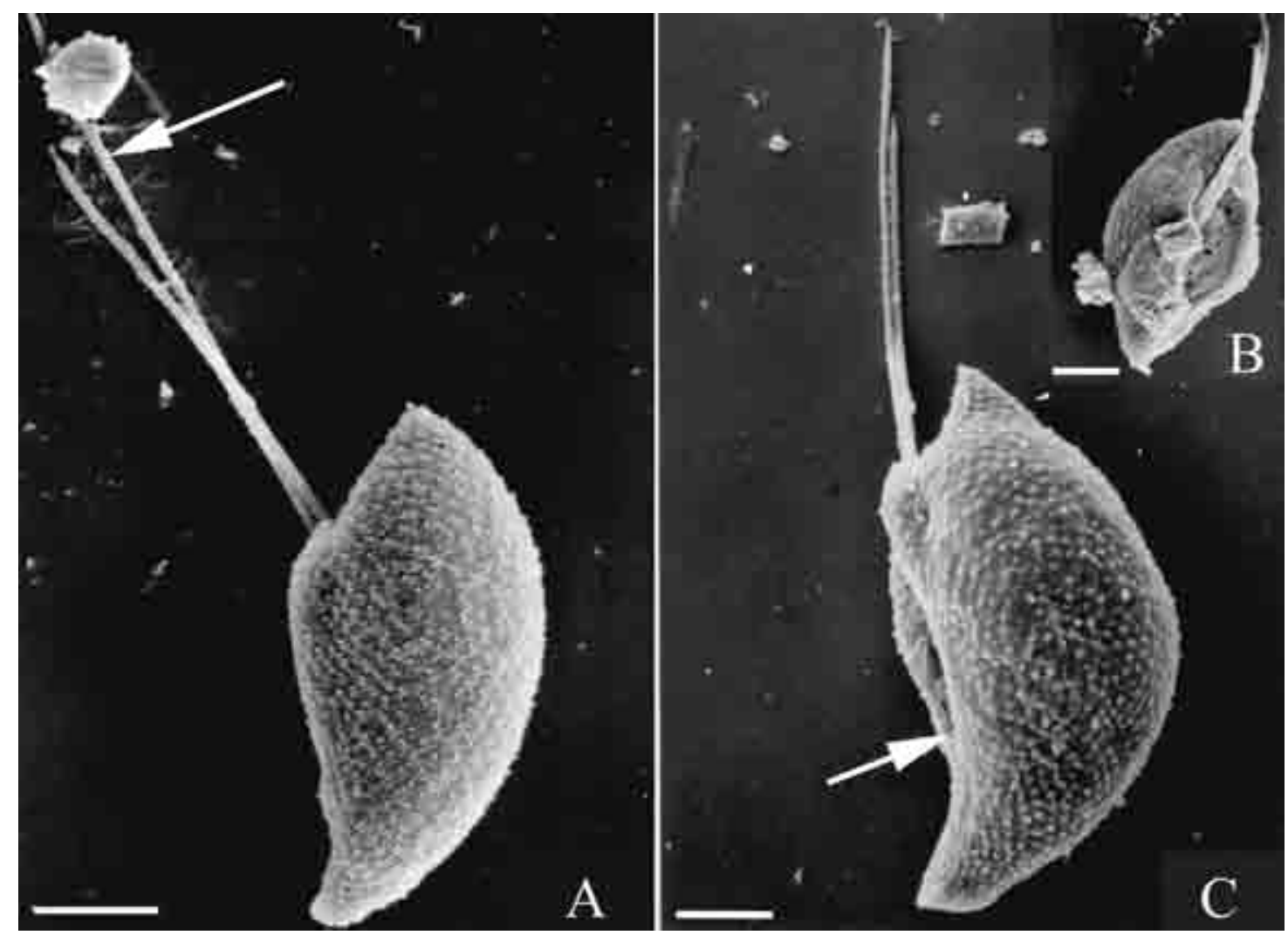

FIG. 12. - Teleaulax amphioxeia from the Mediterranean Sea, SEM, HMDS-dried material. A, a cell in lateral view; note the characteristically longer ventral flagellum (arrow). B, a cell in ventral view, showing the ventral furrow $\mathbf{C}$, a cell in ventro-lateral view; note the extent of the ventral furrow (arrow). Scale bars $=2 \mu \mathrm{m}$.

periplast covering the entire cell surface, including the posterior end (Fig. 11B).

Teleaulax acuta was found in the Sea of Alboran station $\mathrm{C}$ at a depth of $50 \mathrm{~m}$, i.e. below the deep chlorophyll maximum, which was located at $44 \mathrm{~m}$. It also occurred frequently in several time series samples from the port of Barcelona.

Teleaulax acuta has been reported from several geographical localities. The reported populations are not morphologically homogeneous (Table 3), and therefore this apparently wide geographical distribution could conceal a number of distinct species. It is unknown whether or not these geographical populations are also genetically or physiologically distinct from one another.

\section{Teleaulax amphioxeia (Conrad) Hill} (ICBN, ICZN) (Figs. 12, 14D)

Hill, 1992d, pp. 175-176, Figs. 1A-N; Bérard-Therriault et al., 1999, p. 251, pl. 116f-h, pl. 117a, b.

Basionym: Rhodomonas amphioxeia Conrad, 1939, p. 4, Figs. 3-6.

Known geographical distribution: Mediterranean Sea: Sea of Alboran; Northern Atlantic: Baltic Sea
(Hill, 1992d), St. Lawrence estuary and gulf (Bérard-Therriault et al., 1999).

Cells of Teleaulax amphioxeia from the Mediterranean Sea (Figs. 12, 14D) are about 7-14 $\mu \mathrm{m}$ long and 4-7 $\mu \mathrm{m}$ thick. The anterior end of the cells is distinctly rostrate while the posterior end is acute (Fig. 11A). There are two unequal flagella. The longer one is the ventral flagellum and it is about 1 to 1.5 times the cell length (Fig. 11A). The flagella are inserted in a subapical position, and to the lefthand side of the point of flagellar insertion there is a broad ventral furrow extending to about $2 / 3$ the cell length (Figs. 11B, C, 14C). There is a non-plated (sheet-like) periplast over the entire cell surface (Fig. 12C).

Teleaulax amphioxeia bears a general resemblance to Teleaulax acuta but it can be recognised unequivocally thanks to its ventral flagellum, which is characteristically longer than the dorsal one. In addition, unlike T. acuta the furrow of T. amphioxeia is displaced towards the left-hand side of the point of flagellar insertion. Analogous to T. acuta, the acute posterior end of $T$. amphioxeia superficially recalls that of Plagioselmis. However, the pres- 
ence of a sheet-like periplast over the entire cell surface of $T$. amphioxeia makes it possible to tell it apart unequivocally from Plagioselmis.

Teleaulax amphioxeia was found in the Sea of Alboran at stations B, C and CN (Almeria-Oran front) at depths between 25 and $40 \mathrm{~m}$, i.e. above the deep chlorophyll maxima, which were located between 30 and $44 \mathrm{~m}$.

Note on taxonomy and nomenclature. The combination Teleaulax amphioxeia (Conrad) Hill is based on Rhodomonas amphioxeia Conrad (1939). Hill (1992d) examined specimens from the Baltic Sea using light and electron microscopy, which showed that the main distinctive feature of this species compared to other species of Teleaulax is given by the presence of unequal flagella, of which the longer one is the ventral flagellum (Hill, 1992d, p. 176). Clearly, from a taxonomic viewpoint the specimens examined by Hill (1992d) and the Mediterranean ones are all conspecific. However, Conrad's original description of Rhodomonas amphioxeia makes no mention of the main distinctive feature of the Teleaulax amphioxeia of Hill (1992d). Instead, it specifies that Rhodomonas amphioxeia has equal flagella ("les fouets sont égaux", Conrad, 1939, p. 4), as shown also by the illustrations (Conrad, 1939, Figs. 3-6). Therefore, there is little evidence to suggest that the species Rhodomonas amphioxeia (in the original sense of Conrad) is one and the same as the cryptomonad which Hill referred to as Teleaulax amphioxeia, and the cryptomonad studied by Hill (1992d) appears to be a hitherto undescribed species from a formal taxonomic point of view. Thus, a full taxonomic protologue is desirable for it.

\section{Genus Chroomonas Hansgirg (sensu auctorum)}

Vide Hill, 1991b, pp. 135-137.

Chroomonas sp. (Fig. 13A)

Known geographical distribution: So far known only from the Sea of Alboran.

Cells of Chroomonas sp. from the Mediterranean Sea (Fig. 13A) are about 4-6 $\mu \mathrm{m}$ long and 2-3 $\mu \mathrm{m}$ thick. They are elliptical in shape with a slightly narrowed posterior end. There are two equal or subequal flagella about $2 / 3$ the cell length, of which the dorsal one carries the usual double row of hairs (Fig. 13A) and the ventral one a single row. The flagella are inserted in an apical position, and analogous to all known members of this genus a ventral furrow is absent. The periplast is composed of approximately rectangular plates (Fig. 13A), about 0.7-0.8 x 0.4$0.5 \mu \mathrm{m}$ in size in the middle region of the cell and slightly smaller in the posterior region. The periplast band-like structure found in some species of this genus in the posterior region of the cell ("raphe": Hill, 1991b, Fig. 12) appears to be absent.

The examined specimens resemble Chroomonas placoidea Butcher ex Novarino et Lucas owing to the cell size and the size of the periplast plates (Novarino and Lucas, 1993b). However, C. placoidea has a different cell shape and the flagella are unequal, with the longer (dorsal) flagellum between $3 / 4$ and $3 / 2$ the cell length. The Mediterranean specimens differ also from other known members of this genus owing to the size of the periplast plates (see Meyer and Pienaar, 1984; Hill, 1991b; Novarino and Lucas, 1993b; Kristiansen and Kristiansen, 1999), and therefore it is possible that they belong to a hitherto undescribed species. However, for the time being the establishment of a new species is best avoided owing to the relative scarcity of specimens in the examined samples, and general typification questions within the genus (see below).

Chroomonas sp. was found in the Sea of Alboran at stations $\mathrm{A}, \mathrm{B}$ and $\mathrm{C}$ at depths between 45 and 80 $\mathrm{m}$, i.e. at or below the deep chlorophyll maxima, which were located between 35 and $45 \mathrm{~m}$.

Note on generic-level typification and taxonomy. The original description of the genus Chroomonas was based necessarily on light microscopy only (Hansgirg, 1885). Since then, numerous studies have provided this genus with a well-defined and generally agreed ultrastructural identity (for a summary see Hill, 1991b). However, an examination of Hangirg's original type material with the SEM has shown that the type species of Chroomonas has a periplast with hexagonal plates (Novarino and Oliva, 1997; Novarino, 2003). This contrasts with the accepted view that the genus is characterised by rectangular periplast plates. Therefore, based on the systematic importance which is currently attached to periplast features, there is a need for an emended generic description of Chroomonas and this is in preparation. It is also likely that rectangular-plated cells of "Chroomonas" (including the Mediterranean ones examined here) will have to be assigned 


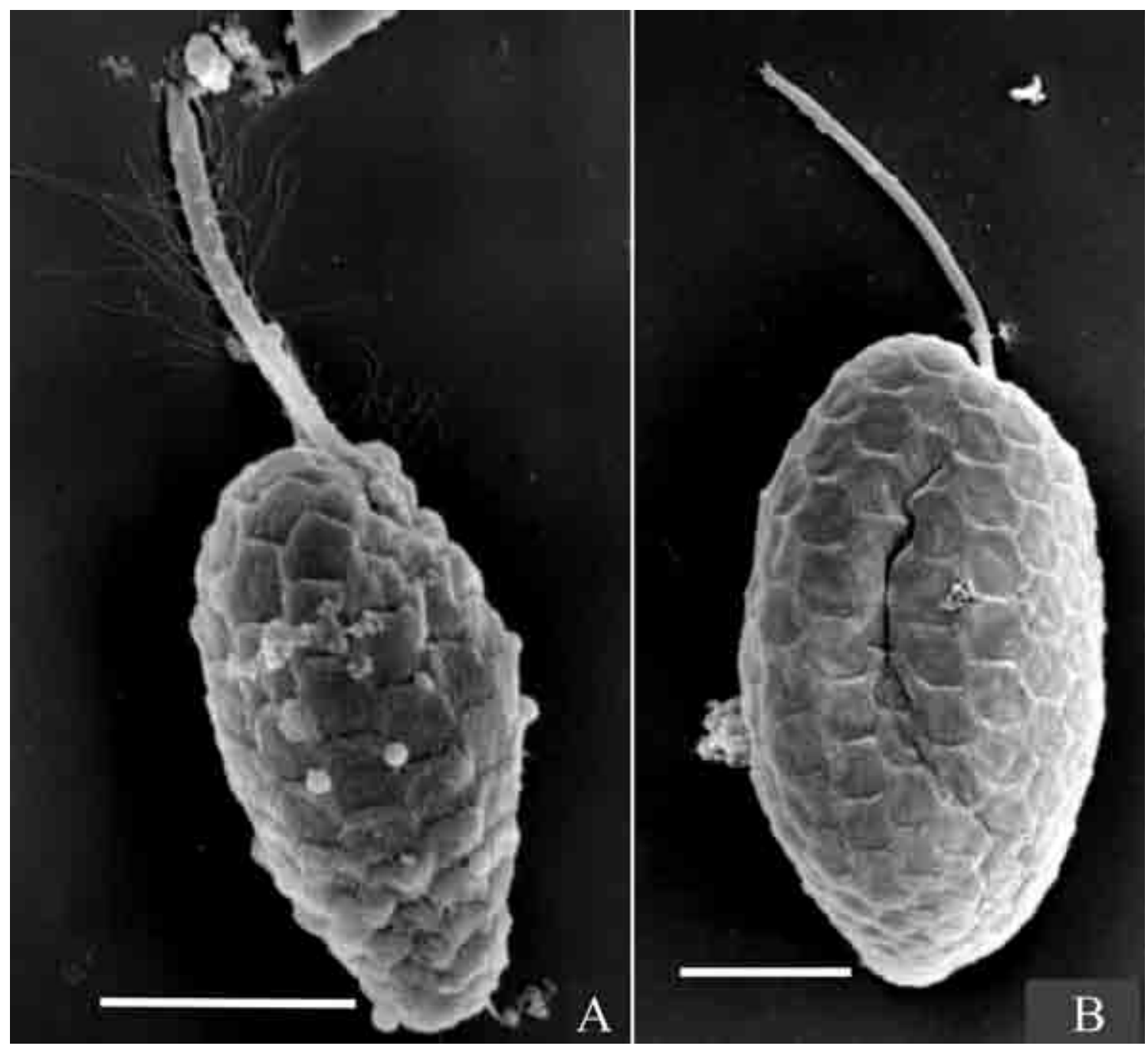

FIG. 13. - Cryptomonads from the Mediterranean Sea, SEM, HMDS-dried material. A, an undetermined species of Chroomonas sensu auctorum, showing rectangular or approximately rectangular periplast plates; this cell is seen in dorsal view. B, Rhinomonas reticulata; this cell is seen in dorso-lateral view and shows the characteristic, hexagonal plates. The vertical crack on the periplast surface is a preparation artefact. Scale bars $=2 \mu \mathrm{m}$.

to a new genus to be described. However, because a formal generic description is not yet available we assign the Mediterranean specimens to Chroomonas (sensu auctorum) for the time being.

\section{Genus Rhinomonas Hill (ICBN, ICZN)}

Hill and Wetherbee, 1988, Phycologia Vol 27, p.356, Figs. 1-18.

Type species: Rhinomonas pauca Hill and Wetherbee, 1988, p. 359, Figs. 1 (holotype), 2-18.

\section{Rhinomonas reticulata (Lucas) Novarino (ICBN, ICZN) (Fig. 13B)}

Novarino, 1991a, p. 244, Figs. 1-6

Basionym: Cryptomonas reticulata Lucas, 1968, Brit. Phycol. Bull. 3 , p. 535, Fig. 1B (holotype), Figs. 6, 7 (paratypes).
Known geographical distribution: Mediterranean Sea: Sea of Alboran; Northern Atlantic: numerous culture strains assigned to $R$. reticulata were originally isolated from Northern Atlantic waters (Novarino, 1991a).

Cells of Rhinomonas reticulata from the Mediterranean (Fig. 13B) are about 6-8 $\mu \mathrm{m}$ long and 3-4 $\mu \mathrm{m}$ thick. There are two equal or subequal flagella about $2 / 3$ the cell length, arising from a circular vestibular opening located close to cell apex. There is no ventral furrow, and any short, notch-like "furrows" on the ventral margin of the vestibular opening are most likely to be shrinkage artefacts arising during specimen preparation for SEM (Novarino, 1991b). Rhinomonas reticulata is also susceptible to other shrinkage artefacts, particularly 


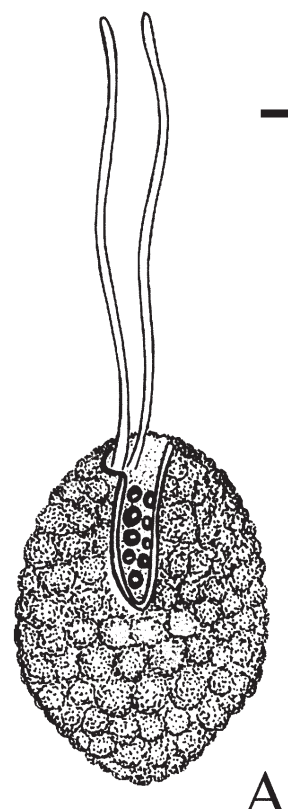

A

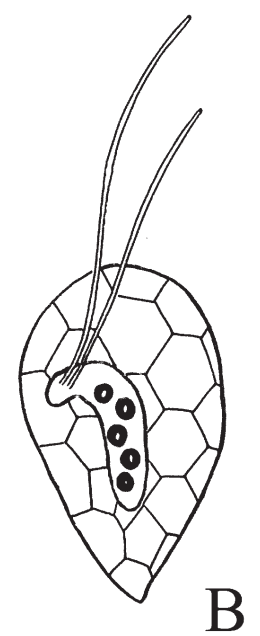

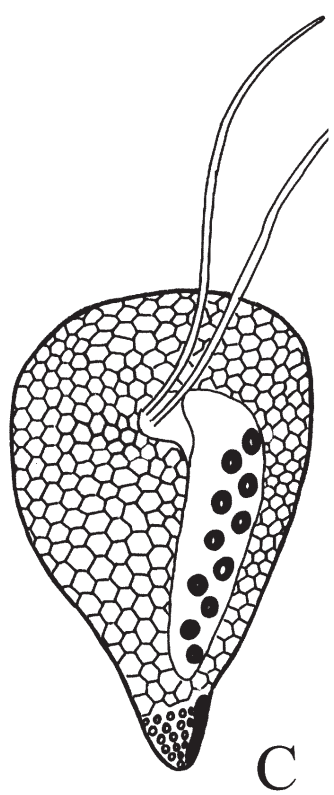

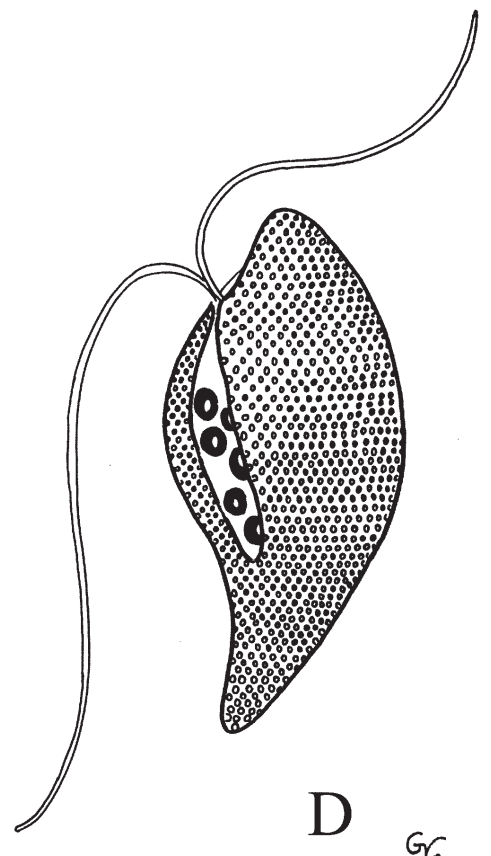

FIG. 14. - Unusual or little-known cryptomonads described in this paper (semi-diagrammatic drawings based on SEM observations). A, Cryptochloris sp (from Novarino et al., 1997, Fig. 5e with permission of the copyright owner). B, Hemiselmis sp. inedit. (original). C, Plagioselmis sp. inedit. (original). D, Teleaulax amphioxeia (original). Scale bar $=2 \mu \mathrm{m}$.

folds and cracks on the dorsal face (Fig. 13A). The periplast is composed of typical hexagonal plates about $0.4-0.5 \mu \mathrm{m}$ in size.

The morphology of Rhinomonas reticulata is highly variable, particularly the size of the periplast plates (Novarino, 1991a). In the Mediterranean specimens the cell size is close to the lower end of the range, while the size of the periplast plates lies at the upper variability limits reported so far (Novarino, 1991a).

Rhinomonas reticulata was found in the Sea of Alboran station $\mathrm{CN}$ at $33 \mathrm{~m}$ depth, i.e. at the deep chlorophyll maximum, which was located at $33 \mathrm{~m}$.

\section{CONCLUSIONS}

During this investigation eleven cryptomonads were identified but the true number of species present could be higher if seasonal variations in species composition were to occur, as is the case in other geographical areas (e.g. Bérard-Therriault et al., 1999). However, such variations could not be investigated here owing to the limited availability of suitable cruises.

Taxonomic identification was based on SEM. Although this observation method is now used more frequently during nanoplankton ecological surveys (Kuylenstierna and Karlson, 1994; Novarino et al.,
1997; Bérard-Therriault et al., 1999; Barlow and Kugrens, 2002), it is still uncommon as a routine identification tool. The SEM appears to be essential for identifying cryptomonads because these flagellates show few taxonomically significant features under the light microscope. Although this survey was based on a high-end field-emission SEM, conventional medium-range instruments also make it possible to identify cryptomonads down to the genus or species levels (Novarino, 1991a, 1991b; Novarino and Lucas, 1993b; Novarino et al., 1994, 1997). Cell surface features (sheet-like versus plated periplast, shape and size of the periplast plates when plates are present, presence or absence of a true, non-artefactual ventral furrow), and flagellar features (absolute and relative length, insertion point) were particularly useful for identifying the Mediterranean specimens. This agrees well with the general systematic importance attached to those characters (Novarino and Lucas, 1993a; Clay et al., 1999), and gives further support to the view that the inclusion of SEM observations in cryptomonad diversity studies may yield significant results (Novarino, 2003).

All of the eleven species found are unequivocal new records for the Mediterranean Sea. Five of them (over $45 \%$ ) have been found or further characterised here for the first time: Cryptochloris sp., Hemiselmis sp. inedit., Hemiselmis sp. 1, Plagioselmis sp. inedit. and an undetermined species of Chroomonas 
sensu auctorum. If this percentage is equal to the proportion of hitherto undescribed species within the cryptomonads as a whole, then it could be speculated that the total number of existing species is in the region of 290 (200 known species x 1.45), or 300 in round figures. This estimate is much more conservative than one already available in the literature (about 1200). Unfortunately it is impossible to compare these estimates because the basis for the higher figure (Andersen, 1992) is unknown, as is the proportion of species names which are synonymous with previously published ones. Nonetheless, for the time being it is best to consider the cryptomonads at least as a moderately species-rich group. Further baseline investigations are necessary in order to gain insight into the true extent of species diversity. It can be speculated that other unexplored geographical areas, including perhaps other areas of the Mediterranean Sea, could also harbour previously unknown cryptomonads. Explorations of entirely new habitats could also prove fruitful, as has been the case with the submarine ikaite columns examined by Kristiansen and Kristiansen (1999).

Seven species found during this survey (Cryptochloris sp., Hemiselmis sp. 2, Plagioselmis prolonga, Plagioselmis nordica, Rhinomonas reticulata, Teleaulax acuta, Teleaulax amphioxeia) are known also from other geographical regions. Although some caution is necessary when comparing electron microscopical reports with traditional reports based on light microscopy, it is still possible that some or all of those species may be cosmopolitan. However, this assumption is based exclusively on a morphological species concept and no information is available on the occurrence of genetic or physiological differentiation on a geographical basis. To date, genetic differentiation has been studied only in a small number of marine nanoplankton protists, e.g. haptophytes (Barker et al., 1994) and dinoflagellates (Montresor et al., 2003). In that respect it would be particularly useful to investigate Rhinomonas reticulata and Teleaulax acuta because the various geographical populations of these species are morphologically variable and it is unknown whether or not morphological variability is paralleled by genetic variability.

So far Chroomonas sp., Hemiselmis sp. 1, Hemiselmis sp. inedit. and Plagioselmis sp. inedit. are known only from the Mediterranean but any comments on their possible endemic status are premature. Nonetheless, during future investigations the possible occurrence of endemic plankton protists in the Mediterranean should always be borne in mind because this area is known to have a higher species diversity as far as the phytoplankton is concerned (Margalef, 1994).

Plagioselmis prolonga was the most widespread and abundant cryptomonad in the examined samples, but in spite of its abundance no cell counts of this species were carried out. Traditional (Utermöhl) counts would have been unreliable because under the light microscope $P$. prolonga can be easily mistaken for other species of Plagioselmis, Teleaulax acuta, or Leucocryptos marina (Braarud) Butcher, as illustrated in a forthcoming study. Furthermore, any SEM-based counts carried out as described elsewhere (Novarino et al., 2002) would have been unrepresentative because the samples examined here were fixed according to different procedures. Nonetheless, it is still likely that the maximum population densities reached by $P$. prolonga in the south-western Mediterranean are high, but in spite of this the total biovolume reached by this or any other cryptomonad of comparable size is very likely to be lower than that of "traditional" primary producers in the microplankton size range (e.g. the large diatoms). However, marine planktonic cryptomonads may have very high intracellular concentrations of chemical constituents (including carbon) compared to microplankton diatoms (Moal et al., 1987). If this were proven to be the case also with Plagioselmis prolonga, then I would hypothesise that this relatively little-known cryptomonad is a key primary producer of carbon in the Mediterranean pelagic ecosystem. Most likely, future ecological work on $P$. prolonga-dealing particularly with its quantitative occurrence and spatio-temporal variability, photosynthetic characteristics, chemical composition and contribution to primary carbon production in the water column - will give valuable insight into the functioning of the pelagic food web in the Mediterranean Sea and elsewhere.

\section{ACKNOWLEDGEMENTS}

The Alboran samples were collected by Gail Lambourne (formerly at the Department of Zoology, The Natural History Museum, London) during a cruise within the EU MATER Project (EU MAS3CT96-0051, Associate Partner no. 9, Principal Investigator Marta Estrada; and Subcontract CSIC ICDM-BM, subcontractor The Natural History Museum, Principal Investigator G. Novarino). The 
Barcelona workshop was funded by an Integrated Action between Spain and France (Reference HF97103, Principal Investigators Dolors Vaqué and Michel Denis) and the EU MATER Project (EU MAS3-CT96-0051, Associate Partner no. 9, Principal Investigator Marta Estrada). I am very grateful to Dolors Vaqué and Michel Denis for organising the workshop, and I also thank Miquel Angel Rodriguez for his enthusiastic technical assistance and handling the small sampling boat off Barcelona. I am also grateful to Emilia Oliva (formerly at The Natural History Museum) for technical assistance, and Ian Lucas (University of Wales Bangor, UK) for comments on a draft of the manuscript.

\section{REFERENCES}

Andersen, R. A. - 1992. Diversity of eukaryotic algae. Biodiv. Conserv, 1: 267-292.

Andreoli, C., C. Tolomio, N. Rascio and R. Talarico - 1986. Some observations on a cryptophycea responsible for a winter red bloom. Giorn. Bot. Ital., 120: 70-71.

Barker, G.L.A., J.C. Green, P.K. Hayes and L.K. Medlin. - 1994 Preliminary results using the RAPD analysis to screen bloom populations of Emiliania huxleyi (Haptophyta). Sarsia, 79: 301306

Barlow, S.B. and P. Kugrens. - 2002. Cryptomonads from the Salton Sea, California. Hydrobiologia, 473: 129-137.

Bérard-Therriault, L., M. Poulin and L. Bossé. - 1999. Guide d'identification du phytoplancton marin de l'estuaire et du golfe du Saint-Laurent incluant également certains protozoaires. Publication spéciale canadienne des sciences halieutiques et aquatiques, 128: $387 \mathrm{pp}$.

Bisalputra, T., J.Y. Cheng, F.J.R. Taylor and N.J. Antia. - 1973. Improved filtration techniques for the concentration and cytological preservation of microalgae for electron microscopy. Can. J. Bot., 51: 371-377.

Booth, B.C., J. Lewin and R.E. Norris. - 1982. Nanoplankton species predominant in the subarctic Pacific in May and June 1978. Deep-Sea Res., 29: 185-200.

Butcher, R.W. - 1952. Contributions to our knowledge of the smaller marine algae. J. Mar. Biol. Ass. U.K., 52: 175-191.

Butcher, R.W. - 1967. An introductory account of the smaller algae of British coastal waters. Part IV: Cryptophyceae. Fish. Invest. London, Ser. 4: 1-54.

Cavalier-Smith, T., J.A. Couch, K.E. Thorsteinsen, P. Gilson, J.A Deane, D.R.A. Hill and G.I. McFadden. - 1996. Cryptomonad nuclear and nucleomorph 18S rRNA phylogeny Eur. J. Phycol., 31: $315-328$

Chang, F.H. - 1983. Winter phytoplankton and microzooplankton populations off the coast of Westland, New Zealand, 1979. N. Z. J. Mar. Freshw. Res., 17: 279-304.

Clay, B.L. and P. Kugrens. - 1999. Characterization of Hemiselmis amylosa sp. nov. and phylogenetic placement of the blue-green cryptomonads $H$. amylosa and Falcomonas daucoides. Protist, 150: 297-310.

Clay, B.L., P. Kugrens and R.E. Lee. - 1999. A revised classification of Cryptophyta. Bot . J. Linn. Soc., 131: 131-151.

Conrad, W. - 1939. Notes protistologiques. XII - Sur quatre Cryptomonadines rouges. Bull. Mus. r. Hist. nat. Belg., 15: 1-5.

Dame, R., M. Alber, D. Allen, M. Mallin, C. Montague, A. Lewitus, A. Chalmers, R. Gardner, C. Gilman, B. Kjerfve, J. Pinckney and N. Smith. - 2000. Estuaries of the south Atlantic coast of North America: Their geographical signatures. Estuaries, 23: 793-819.

Delgado, M. and J.-M. Fortuño. - 1991. Atlas de fitoplancton del Mar Mediterráneo. Sci. Mar., 55 (Suppl. 1): 1-133.

Droop, M.R. - 1955. Some new supra-littoral Protista. J. Mar. Biol.
Ass. UK, 34: 233-245.

Gervais, F. - 1997. Cryptomonas undulata spec. nov., a new freshwater cryptophyte living near the chemocline. N. Hedwigia, 65: 353-364.

Haigh, R., F.J.R. Taylor and T.F. Sutherland. - 1992. Phytoplankton ecology of Sechelt Inlet, a fjord system of the British Columbia coast. 1. General features of the nanoplankton and microplankton. Mar. Ecol. Progr. Ser., 89: 117-134.

Hansgirg, A. - 1885. Anhang zu meiner Abhandlung - Ueber den Polymorphismus der Algen. Bot. Centralbl., 23: 229-233.

Hill, D.R.A. - 1991a. A revised circumscription of Cryptomonas (Cryptophyceae) based on examination of Australian strains. Phycologia, 30: 170-180.

Hill, D.R.A. - 1991b. Chroomonas and other blue-green cryptomonads. J. Phycol., 27: 133-145.

Hill, D.R.A. - 1992a. Hemiselmis virescens Droop (Cryptophyceae). Baltic Sea phytoplankton identification sheet n. 7 . Ann. Bot. Fenn., 29: 163-164.

Hill, D.R.A. - 1992b. Plagioselmis prolonga Butcher (Cryptophyceae). Baltic Sea phytoplankton identification sheet n. 8 Ann. Bot. Fenn., 29: 165-166.

Hill, D.R.A. - 1992c. Teleaulax acuta (Butcher) Hill (Cryptophyceae). Baltic Sea phytoplankton identification sheet n. 12 . Ann. Bot. Fenn., 29: 173-174.

Hill, D.R.A. - 1992d. Teleaulax amphioxeia (Conrad) Hill, comb. nov. (Cryptophyceae). Baltic Sea phytoplankton identification sheet n. 13. Ann. Bot. Fenn., 29: 175-176.

Hill, D.R.A. and R. Wetherbee. - 1988. The structure and taxonomy of Rhinomonas pauca gen. et sp. nov. (Cryptophyceae). Phycologia, 27: 355-365.

Hill, D.R.A. and R. Wetherbee. - 1986. Proteomonas sulcata gen. et sp. nov. (Cryptophyceae), a cryptomonad with two morphologically distinct and alternating forms. Phycologia, 25: 521-543.

Hill, D.R.A. and R. Wetherbee. - 1989. A reappraisal of the genus Rhodomonas (Cryptophyceae). Phycologia, 28: 143-158.

Hill, D.R.A. and R. Wetherbee. - 1990. Guillardia theta gen. et sp. nov. (Cryptophyceae). Canadian J. Bot., 68: 1873-1876.

Hoef-Emden, K., B. Marin and M. Melkonian. - 2002. Nuclear and nucleomorph SSU rDNA phylogeny in the cryptophyta and the evolution of cryptophyte diversity J. Mol. Evol., 55: 161-179.

Klaveness, D. - 1985. Classical and modern criteria for determining species of Cryptophyceae. Bull. Plankton Soc. Japan, 32: 111-123.

Kristiansen, J. and Aa. Kristiansen. - 1999. A new species of Chroomonas (Cryptophyceae) living inside the submarine ikaite columns in the Ikkafjord, Southwest Greenland, with remarks on its ultrastructure and ecology. Nord. J. Bot., 19: 747-758.

Kugrens, P. and R.E. Lee. - 1987. An ultrastructural survey of cryptomonad periplasts using quick-freezing freeze fracture techniques. J. Phycol., 23: 365-376.

Kugrens, P., B.L. Clay and R.E. Lee. - 1999. Ultrastructure and systematics of two new freshwater red cryptomonads, Storeatula rhinosa, sp nov and Pyrenomonas ovalis, sp nov J. Phycol., 35: 1079-1089.

Kugrens, P., R.E. Lee and R.A. Andersen. - 1986. Cell form and surface patterns in Chroomonas and Cryptomonas cells (Cryptophyta) as revealed by scanning electron microscopy. J. Phycol. , 22: 512-525.

Kugrens, P., R.E. Lee and R.A. Andersen. - 1987. Ultrastructural variations in cryptomonad flagella. J. Phycol., 23: 511-518.

Kuylenstierna, M. and B. Karlson. - 1994. Seasonality and composition of pico- and nanoplanktonic cyanobacteria and protists in the Skagerrak. Botanica mar., 37: 17-33.

Lucas, I.A.N.. - 1968. Three new species of the genus Cryptomonas (Cryptophyceae). Brit. Phycol. Bull., 3: 535-541.

McFadden, G.I., P.R. Gilson and D.R.A. Hill. - 1994. Goniomonas. - Ribosomal-RNA sequences indicate that this phagotrophic flagellate is a close relative of the host component of cryptomonads. Eur. J. Phycol. , 29: 29-32.

Margalef, R.. - 1969. Composición específica del fitoplancton de la costa catalano-levantina (Mediterráneo occidental) en 19621967. Inv. Pesq., 33: 345-380.

Margalef, R. - 1994. Through the looking glass: how marine phytoplankton appears through the microscope when graded by size and taxonomically sorted. Sci. Mar., 58: 87-101.

Marin, B., M. Klingberg and M. Melkonian. - 1998. Phylogenetic relationships among the Cryptophyta: Analyses of nuclear- 
encoded SSU rRNA sequences support the monophyly of extant plastid-containing lineages. Protist, 149: 265-276.

Meyer, S.R. and R.N. Pienaar. - 1984. The microanatomy of Chroomonas africana n. sp. (Cryptophyceae). S. Afr. J. Bot., 3: 306-319.

Moal, J., V. Martin-Jezequel., R.P. Harris, J.-F. Samain and S.A. Poulet. - 1987. Interspecific and intraspecific variability of the chemical composition of marine phytoplankton. Oceanol. Acta, 10: $339-346$

Montresor, M., S. Sgrosso, G. Procaccini and W.H.C.F. Kooistra. 2003. Intraspecific diversiity in Scrippsiella trochoidea (Dinophyceae): evidence for cryptic species. Phycologia, 42: 56-70.

Morrall, S. - 1980. Ultrastructure of the Cryptophyceae, including cyst formation and trichocyst substructure. Ph.D. thesis, Imperial College, University of London, UK.

Novarino, G. - 1991a. Observations on Rhinomonas reticulata comb. nov. and Rhinomonas reticulata var. eleniana var. nov. (Cryptophyceae), with comments on the genera Pyrenomonas and Rhodomonas. Nord. J. Bot., 11: 243-252.

Novarino, G. - 1991b. Observations on some new and interesting Cryptophyceae. Nord. J. Bot., 11: 599-611.

Novarino, G. - 2003. A companion to the identification of cryptomonad flagellates $($ Cryptophyceae $=$ Cryptomonadea $)$ Hydrobiologia, 502: 225-270.

Novarino, G. and M.G. Gilbert. - 2002. Proposal to conserve the name Cryptochloris J. Schiller (Cryptophyceae) against Cryptochloris Benth. (Poaceae). Taxon (in press).

Novarino, G. and I.A.N. Lucas. - 1993a. Some proposals for a new classification system of the Cryptophyceae. Bot. J. Linn. Soc., 111: 3-21.

Novarino, G. and I.A.N. Lucas. - 1993b. A comparison of some morphological characters in Chroomonas ligulata sp. nov. and C. placoidea sp. nov. (Cryptophyceae). Nord. J. Bot., 13: 583-591.

Novarino, G. and I.A.N. Lucas. - 1995. A zoological classification system of cryptomonads. Acta Protozoologica, 34: 173-180

Novarino, G. and E. Oliva. - 1998. Typification and ultrastructural characterization of long-described flagellate taxa based on original type material. In: The Flagellates Symposium, University of Birmingham, 7-11 September 1998 (abstract).

Novarino, G., I.A.N. Lucas and S. Morrall. - 1994. Observations on the genus Plagioselmis (Cryptophyceae). Cryptogamie-Algol., 15: 87-107.

Novarino, G., D.K. Mills and F. Hannah. - 1997. Pelagic flagellate populations in the southern North Sea, 1988-89. I. Qualitative observations. J. Plankt. Res., 19: 1081-1109.

Novarino, G., E. Oliva and B. Pérez-Uz. - 2002. Nanoplankton protists from the western Mediterranean Sea. I. Occurrence, ultrastructure, taxonomy and ecological rôle of the mixotrophic flagellate Ollicola vangoorii $($ Chrysomonadidae $=$ Chrysophyceae p.p.). Sci. Mar., 66: 233-247.

Parke, M. - 1949. Studies on marine flagellates. J. Mar. Biol. Ass. $U K, 28: 255-286$.

Robinson, C., S.D. Archer and P.J.L. Williams. - 1999. Microbial dynamics in coastal waters of East Antarctica: plankton production and respiration. Mar. Ecol. Progr. Ser., 180: 23-26.

Santore, U.J. - 1977. Scanning electron microscopy and comparative micromorphology of the periplast of Hemiselmis rufescens, Chroomonas sp., Chroomonas salina and members of the genus Cryptomonas (Cryptophyceae). Br. Phycol. J., 12: 255-270.

Santore ,U.J. - 1982. The ultrastructure of Hemiselmis brunnescens and Hemiselmis virescens with additional observations on Hemiselmis rufescens and comments on the hemiselmidaceae as a natural group of the Cryptophyceae. Br. Phycol. J., 17: 81-99.

Santore, U.J. - 1984. Some aspects of the taxonomy in the Cryptophyceae. New Phytol., 98: 627-646.

Schiller, J. - 1925. Die planktontischen Vegetationen des adriatischen Meeres. B. Chrysomonadina, Heterokontae, Cryptomonadina, Eugleninae, Volvocales. I . Systematischer Teil. Arch. Protistenk., 53: 59-123

Sommer, U. - 1982. Vertical niche separation between two closely related planktonic flagellate species (Rhodomonas lens and Rhodomonas minuta v. nannoplanctica). J. Plankt. Res., 4: 137-142.

Throndsen, J. - 1983. Ultra- and nanoplankton flagellates from coastal waters of Southern Honshu and Kyushu, Japan (including some results from the western part of the Kuroshio off Honshu). Working party on taxonomy in the Akashiwo Mondai Kenkyukai Fishing Ground Preservation Division, Research Department, Fisheries Agency, Japan, 62 pp.

Wetherbee, R., D.R.A. Hill and G.I. McFadden. - 1986. Periplast structure of the cryptomonad flagellate Hemiselmis brunnescens. Protoplasma, 131: 11-22.

Wetherbee, R., D.R.A. Hill and S.J. Brett. - 1987. The structure of the periplast components and their association with the plasma membrane in a cryptomonad flagellate. Can. J. Bot., 65: 10191026.

Scient. ed.: M. Estrada 